\title{
The Phylogenetic Component of Cooperative Breeding in Perching Birds
}

\section{Citation}

Edwards, Scott V., and Shahid Naeem. 1993. The Phylogenetic Component of Cooperative Breeding in Perching Birds. American Naturalist 141(5): 754-789.

\section{Published Version}

http://dx.doi.org/10.1086/285504

\section{Permanent link}

http://nrs.harvard.edu/urn-3:HUL.InstRepos:2689178

\section{Terms of Use}

This article was downloaded from Harvard University's DASH repository, and is made available under the terms and conditions applicable to Other Posted Material, as set forth at http:// nrs.harvard.edu/urn-3:HUL.InstRepos:dash.current.terms-of-use\#LAA

\section{Share Your Story}

The Harvard community has made this article openly available.

Please share how this access benefits you. Submit a story.

\section{Accessibility}




\title{
THE PHYLOGENETIC COMPONENT OF COOPERATIVE BREEDING IN PERCHING BIRDS
}

\author{
Scott V. Edwards and Shahid Naeem* \\ Museum of Vertebrate Zoology and Department of Integrative Biology, University of California, \\ Berkeley, California 94720
}

Submitted February 14, 1991; Revised November 12, 1991; Accepted November 18, 1991

\begin{abstract}
The appreciation by earlier workers of the importance of studying avian cooperative breeding $(\mathrm{CB})$ in an explicitly phylogenetic context has waned in most recent studies of the subject. Newer statistical and conceptual methods correct for correlations among species inherent in their phylogenetic relationships and are used to study the evolution and adaptive status of $\mathrm{CB}$ in the context of phylogenetic trees. Statistical, simulation, and phylogenetic analyses of the taxonomic distribution of $\mathrm{CB}$ among passerine genera confirm the suspicion that $\mathrm{CB}$ is nonrandomly distributed among genera and extend the conclusion of E. Russell that CB may be ancient in some lineages, many of which include well-studied species. Phylogenetic reconstruction of ancestral states of ecological factors hypothesized to have promoted CB revealed a variety of temporal relationships between the inferred invasion of selective environments and the origin of $\mathrm{CB}$ that were not immediately apparent from nonphylogenetic analyses and that clarified the mechanistic relationship between these events. In some lineages the persistence of $\mathrm{CB}$ after substantial change in the selective environments presumed responsible for its origin suggests that "phylogenetic inertia" may partly explain the observed taxonomic distribution of CB. Phylogenetic effects cannot explain the observed plasticity and context-specific variation in many aspects of $\mathrm{CB}$ and helping; the joint effects of phylogeny and ecology for explaining such variation are illustrated. The data suggest that many lineages experience evolutionary forces promoting long-term stasis in life histories conducive to $\mathrm{CB}$ in addition to the bettercharacterized environmental responses modifying its short-term expression.
\end{abstract}

One might ask if communal breeding [in birds] is adaptive to members of populations exhibiting it now as it was to the ancestors of those populations living under possibly quite different environmental influences. Communal behavior involves complex social interactions; it conceivably could have become "locked in" to the behavioral repertoire of a species. [Dow 1980, p. 135]

Historical reconstruction of evolutionary events is a notoriously difficult task yet is crucial to a thorough understanding of evolutionary phenomena. In part because of a resurgence in phylogenetic analyses, the importance of history and phylogeny for modeling a wide variety of problems in behavior, ecology, and evolution is again being appreciated (Huey 1987; McLennan et al. 1988; Donoghue 1989; Höglund 1989; Prum 1990; Björklund 1991; Kirkpatrick and Ryan 1991; Ligon 1992).

* Present addresses: S.V.E., Center for Mammalian Genetics and Department of Pathology, 100275, University of Florida, Gainesville, Florida 32610; S.N., NERC Centre for Population Biology, Imperial College at Silwood Park, Ascot, Berkshire, SL5 7PY, United Kingdom. 
Several of the early reviews of helping behavior and cooperative (communal) breeding (CB) in birds were written by ornithologists who not only appreciated comparative approaches but were trained as systematists (Skutch 1961; Selander 1964; Rowley 1968; Harrison 1969; Brown 1978). The assumption that cooperative breeding might show concordance with phylogeny, indeed corroborate phylogenetic relationships in many cases (Davis 1948; Hardy 1961, 1969; Brown 1974; Fry 1977), was a natural extension of the extensive groundwork in comparative behavioral methods laid by earlier workers (e.g., Lorenz 1950; Mayr 1958; reviewed in McLennan et al. 1988; Wcislo 1989). Nonetheless, a reassessment of the bearing of phylogeny on our perception of cooperative breeding is timely for at least four reasons.

First, despite this earlier work, it has been argued that the use of comparative or explicitly phylogenetic methods and the perspective they engender has waned in the behavioral and ecological sciences generally (McLennan et al. 1988; Brooks and McLennan 1990; Ligon 1992). In important ways the study of CB in birds has developed largely within the confines of ecological and behavioral theory designed to test hypotheses of the current adaptiveness of individual and group behavior under varying environmental and social pressures. Since the early observations of Skutch (1935), the majority of empirical and theoretical workers have tried to determine the short- and long-term advantages incurred by individuals assisting other, often related individuals in rearing their offspring (reviewed in Brown 1987). The advent and refinement of inclusive fitness theory (Hamilton 1964; Williams 1966) and early field observations of social species (Yamashina 1938; Rowley 1965) later directed the practice of such studies by focusing attention on the life histories and reproductive success of individuals and groups within cooperatively breeding species. Thus, in fact, most studies have sought factors facilitating the evolution of CB largely among social, genetic, or environmental variables currently experienced by individuals within groups or in particular habitats and have not considered comparative or historical methods of causal inference. When cooperatively breeding populations or species are compared, current environmental or demographic differences are generally presumed responsible for the differences in social structure and dynamics observed.

Second, the earlier comparative studies could not benefit from the recent development of more sophisticated statistical and conceptual methods for studying the evolution of traits and their relationship to hypothesized causal factors (CluttonBrock and Harvey 1979; Ridley 1983; Brooks 1985; Cheverud et al. 1985; Felsenstein 1985; Burt 1989; Grafen 1989; Gittleman and Kot 1990; Maddison 1990; reviewed in Brooks and McLennan 1990; Harvey and Pagel 1991; Lynch 1991). For example, historically, the search for ecological correlates of CB was not conducted in phylogenetic frameworks (Harrison 1969; Dow 1980; Ford et al. 1988) and therefore could not consider the possibility that hypothesized "correlates" could be shared ancestrally among cooperative breeders and their noncooperative relatives. Since all species necessarily belong to a hierarchically and temporally clustered phylogeny, only such methods account for the historical component of these traits and their environments and circumvent statistical problems incurred by the correlation among species that is inherent in their phylogeny. 
Third, for many evolutionary questions, the definition of adaptation and the criteria required for its identification have been radically refined (Gould and Vrba 1982; Greene 1986; Coddington 1988; Baum and Larson 1991); these definitions and criteria, for which a phylogenetic context is usually necessary, have not been applied in the study of $\mathrm{CB}$. For example, in the unlikely event that cooperatively breeding species were found exclusively in one set of ecological circumstances, evidence that $\mathrm{CB}$ was an adaptation to those circumstances would still be lacking by these definitions, because $\mathrm{CB}$ had not been shown to have arisen coincidentally with (on the same branch as) circumstances that were novel ("derived") with respect to an ancestral state. The use of such phylogenetic protocols for identifying adaptations can help clarify the temporal and mechanistic relationship of hypothesized causal factors to the origin of traits of interest.

Finally, despite an increasing number of phylogenetic studies of social behavior, particularly in social insects (Baroni Urbani 1989; Carpenter 1989; Ross and Carpenter 1991), a discussion of the limits of phylogenetic approaches for furthering our understanding of $\mathrm{CB}$ in birds has only recently begun (Heinsohn et al. 1990). Does the diversity among species and evidence for short-term geographical and temporal variation in helping render CB inappropriate for analysis at higher taxonomic levels? The development of methods for treating continuous variables and dissection of CB into its components offer ways of accommodating evidence of polymorphism and ecological response into phylogenetic analyses.

Throughout this article CB means "a system of breeding that is characterized by the normal presence of helpers at some or all nests"' (Brown 1987, p. 298), where a helper is "an individual that performs parent-like behavior toward young that are not genetically its own offspring"' (p. 300). Examination of a current list of known avian cooperative breeders (Brown 1987, table 2.2) reveals some striking patterns. First, several genera contain a large number of cooperative breeders relative to the total number of species in those genera. That the distribution of CB in birds appears nonrandom has been noted before (see, e.g., Brown 1987, p. 34), but this conclusion needs to be verified and quantified, because even for a randomly distributed trait, a certain number of genera (especially small ones) are expected to consist entirely of cooperative species, a pattern which would potentially give a false impression of a clumped distribution. Second, the cooperatively breeding species in genera or families are often sister taxa (e.g., nuthatches Sitta pygmaea and Sitta pusilla: Norris 1958; woodpeckers Melanerpes formicivorus and Melanerpes cruentatus: Short 1970, 1982; white-winged choughs [Corcorax] and apostlebirds [Struthidea: Corcoracinae]: Sibley and Ahlquist 1985). Finally, the recent suggestion by Sibley and Ahlquist (1985; Sibley et al. 1988) that many endemic Australo-Papuan passerine genera may form a monophyletic group relative to their Palearctic counterparts suggests a phylogenetic underpinning of the large number of CB passerines known to occur in Australia (Rowley 1976; Dow 1980; Brown 1987, p. 36; Ford et al. 1988; Russell 1989). Each of these facts suggests that there may be a phylogenetic component to the taxonomic distribution of CB operating in diverse avian lineages. The goal of this article is to detect and interpret this component and thereby reopen a discussion of its bearing on our perception of $\mathrm{CB}$ in perching birds, order Passeriformes. 


\section{METHODS}

\section{Species List}

The base list of the 166 cooperatively breeding passerine species (App. A) was extracted from table 2.2 of Brown (1987). Only currently published records of helping were included in this table; many species for which there was only circumstantial evidence were not. The number of species within genera was counted for each of the 97 genera possessing at least one cooperative breeder (Morony et al. 1975; Howard and Moore 1984). For all subsequent analyses, every genus was assumed to delimit a monophyletic group.

\section{Null Model of Taxonomic Distribution}

If $N_{\mathrm{S}}$ is the observed number of species in a given genus, $C$ is 140 (the total number of cooperatively breeding species in the 71 polytypic genera), and $T$ is 840 (the sum of the species in the 71 polytypic genera), the expected number of cooperative breeders in a given genus $\left(E_{i}\right)$ was calculated as

$$
E_{i}=N_{\mathrm{S}}(C / T)
$$

(Removing the 26 cooperative monotypic genera in statistical analyses to avoid bias in the data toward completely cooperative genera left 71 polytypic genera available for analysis.) This approach redistributes the 140 cooperatively breeding species into only those genera containing at least one cooperative breeder already, thereby rendering it a highly conservative test.

\section{Is $C B$ in Passerines Nonrandomly Distributed among Genera? A Simulation Model}

Using a simulation model, we asked whether the number of genera "rich" in cooperative breeders is greater than that expected if $\mathrm{CB}$ were randomly distributed among genera. The expectation of this number was evaluated using a simulation in which a pool of 140 cooperative species was defined, one cooperative species was assigned to each genus to mimic the criterion for entry into the original data set of 71 genera, and the 69 remaining cooperative species in the pool were then assigned at random to the 71 genera. For six levels of "richness,", an expected distribution of the number of genera rich in CB was generated by running this sampling procedure 1,000 times. This method has the advantage of preserving in the simulation the sizes of genera observed in the data set; thus, in the simulations as well as in the data set, small genera have a higher probability of showing a high proportion of cooperative breeders than do large genera. However, because taxonomic rank does not contain complete hierarchical information, this type of analysis assumes that the relationships of species within genera and of the 71 genera to each other are completely unresolved.

\section{Phylogenetic Analyses}

Phylogenetic trees for species within particular genera or higher taxa were obtained from the literature; relationships based on "overall similarity" of taxa 
(phenograms) were hypothesized to represent phylogenetic relationships. In no case were data on the state of $\mathrm{CB}$ used as data to construct these phylogenies, except to group species in the case of unresolved branching patterns (Maddison 1989).

Categorical data.-We assigned binary states of " +" (cooperative) or " - " (noncooperative) to each species. As in several other surveys of CB (see, e.g., Dow 1980; Ford et al. 1988), no attempt was made to account for variation in the other aspects of CB (e.g., temporal or geographical variation, male helpers only, monogamous or polygynandrous mating system, etc.; see Discussion). The computer program PAUP (version 3.0g; Swofford 1990) was used to plot the distribution of $\mathrm{CB}$ and reconstruct ancestral states on phylogenies by the criterion of parsimony or character optimization (Maddison et al. 1984), in which that reconstruction involving the fewest number of changes is considered the best. When two or more equally parsimonious reconstructions were available, we illustrated the one in which the number of origins of $\mathrm{CB}$ was minimized, as is often done when dealing with "complex" characters (Le Quesne 1974). In each case our primary goal was to identify groups in which $\mathrm{CB}$ may be shared primitively rather than to postulate specific sequences of gain and loss of $\mathrm{CB}$; the fact that $\mathrm{CB}$ arose along any internal branch in the trees is more important for much of our argument than which internal branch. In phylogenetic analyses of genera, a genus was characterized as cooperative if it was monotypic or if a greater than "random" number of species in that genus were cooperative breeders as judged by the null model. Whereas in the simulations we adhered primarily to the data in Brown's (1987) table 2.2, in the phylogenetic analyses we integrated more recent data as much as possible.

Phylogenetic analysis of hypothesized ecological correlates of $C B$. - The interpretation of the taxonomic distribution of CB depends not on whether hypothesized ecological factors co-vary among species (which they presumably do) but how they co-vary with respect to the phylogenetic origins of $\mathrm{CB}$. Of the numerous ecological and demographic factors said to favor the evolution of $\mathrm{CB}$, we chose for reanalysis five, three of which were summarized by Ford et al. (1988) in a survey of cooperative and noncooperative Australian birds: ground foraging, insectivory, and lack of seasonality of habitat (equivalent to eucalypt or semiarid forest). In addition, we considered aridity of habitat and a demographic descriptor, sedentariness, both of which have been proposed as correlates of CB (Harrison 1969; Brown 1987). We scored each species in particular genera and close relatives (outgroups) for presence or absence of these traits, noting polymorphism when evidence from the literature was available. We then reconstructed changes in these traits along the tree as done for $\mathrm{CB}$ above.

Because the reconstructions of $\mathrm{CB}$ on the trees generally involved one or a few origins per group, we could not hope to achieve statistically significant associations of $\mathrm{CB}$ and other variables within any taxonomic group using existing tests that assume parsimony (Ridley 1983; Maddison 1990). We proceed cautiously in our a posteriori interpretation of one or a few constellations of traits on phylogenetic trees. Although the trait of interest may be deemed an adaptation to a hypothesized factor because it displays a few instances of appropriate relationship 

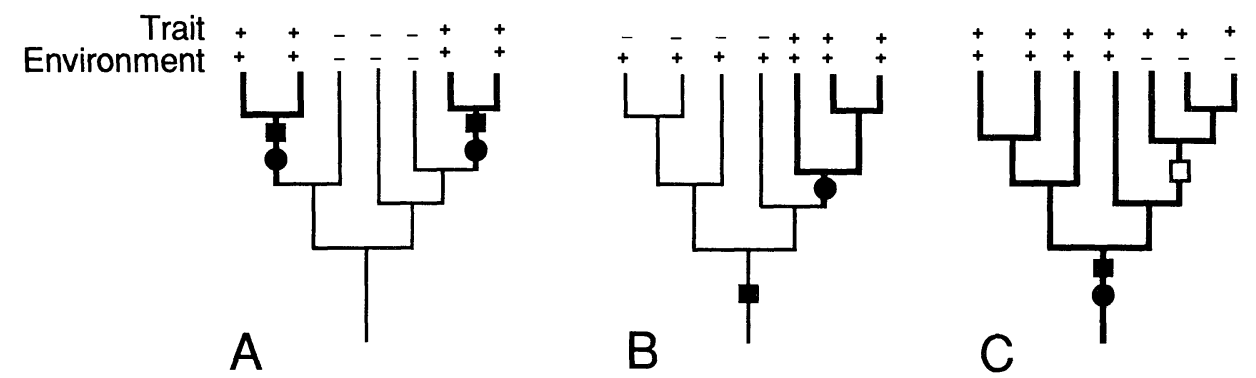

FIG. 1.- Three hypothetical relationships between an organismal trait and an environmental factor reconstructed on a phylogenetic tree. A minus sign or plus sign signifies the presence or absence of a trait or hypothesized selective environment, respectively, for that taxon. Solid circles and squares represent the inferred origin of the trait or selective environment, respectively; the open square in $C$ represents the inferred loss of the selective environment. $A$, A case of coincidental invasion of the selective environment and origin of the trait; here, the environment is a true "ecological correlate" of the trait that responds rapidly to the novel environment. $B$, A situation in which the invasion of the hypothesized selective environment precedes the inferred origin of the trait; the selective environment bears an unknown relationship to the origin of the trait and could be either essential for (but not sufficient) or irrelevant to the origin of the trait. C, A case of "phylogenetic inertia," in which the trait of interest persists in descendants after the hypothesized selection pressure has ceased to operate (open square). Inspired by Greene (1986), Coddington (1988), and Baum and Larson (1991).

to that factor, nonetheless, inferring a causal relationship from these associations would not be supported by the criteria of existing parsimony tests. Despite this difficulty, we studied the relationship between the inferred invasion of particular selective (ecological) "regimes" (Baum and Larson 1991) and the inferred origin of $\mathrm{CB}$ according to the scheme in figure 1, pending the analysis of more data for multiple, independent phylogenetic tests of hypotheses.

Partitioning continuous variables into phylogenetic and ecological ("adaptive") components. - In at least one respect, the ability of statistical methods to cleanly separate the effects of shared ancestry from those of recent adaptation is compromised because many methods attribute all recent, convergent evolution in these traits to the phylogenetic, rather than the adaptive, component (Cheverud et al. 1985). Nonetheless, such methods can be highly instructive. We ask two questions for continuous traits in related species nested in a phylogeny. First, for a given descendant species, on the average how much of the trait value is truly derived (i.e., newly evolved), and how much was already present in the species' most recent ancestor? Second, how much of the observed interspecific variance in a trait can be explained by phylogenetic correlations among species? To answer the first question, we used the method of Huey and Bennett (1987) to calculate trait values for ancestral taxa in a phylogeny; this method minimizes the sum of the squares of evolutionary change along each branch of a tree (see Losos 1990). Then, for each ancestor/descendant pair, we calculated the phylogenetic component of the trait value as the proportion of the value in the descendant taxon already present in the ancestral taxon; if the direction of change in the trait value 
from ancestor to descendant underwent a reversal relative to the net change in the complete lineage of a species, we assumed such change to be solely the result of ecological modification. The distribution of the phylogenetic components of each descendant trait value, as well as the component of the trait value in each extant species in the tree, provides a measure of how much accumulated change in a trait represents change already accrued in ancestral taxa.

In addition, we used phylogenetic autocorrelation models (Cheverud et al. 1985; Gittleman and Kot 1990), which propose that the values for continuous traits in a given species consist of a phylogenetic component due solely to the values of other species of varying relatedness and a residual component that is unexplained by the values of relatives of the species. These methods also seek to quantify the degree to which variation in trait values among species is explained by phylogenetic relationships and are most effective when the trait values for each species are accompanied by quantitative molecular or other data on degrees of relatedness among the species.

\section{RESULTS}

\section{Tests of Nonrandom Distribution of Cooperative Breeding}

The 166 cooperatively breeding passerine birds in the 97 genera extracted from table 2.2 of Brown (1987) comprise $75 \%$ of the documented cases of CB in birds, with true songbirds (oscines) making up $98 \%$ of these. The number of species showing CB varied widely among genera (range: 10 of 27 babbler species [Turdoides] to 1 of 61 white-eye species [Zosterops]). The proportion of species showing CB also ranged widely (e.g., 1.0 in Australian babblers [Pomatostomus; see Boehm 1979 for Pomatostomus ruficeps] and robins [Eopsaltria] to 0.016 [Zosterops]). Other genera rich in cooperative breeders include starlings (Spreo: 4 of 6), wrens (Campylorhynchus: 6 of 10), and bell-miner honeyeaters (Manorina: 3 of 4; see App. A).

The relative cumulative frequency distributions of the number of cooperative and noncooperative breeders per genus departed significantly from expectation under the null model (eq. [1]), in which the number of cooperative breeders per genus is solely a function of genus size (Kolmogorov-Smirnov goodness-of-fit test, $D=0.148, P<.01$ ). A replicated goodness-of-fit test of the differences between the observed ratios of cooperatively to noncooperatively breeding species within the 71 genera and the empirically derived expected ratio of 140:700 indicated a highly significant difference between observed and expected ratios $\left(G_{\mathrm{T}}=201.38, \mathrm{df}=71, P<.0001\right)$. The magnitude and direction of deviations from expectation varied considerably among genera as indicated by the large interaction term $\left(G_{\mathrm{H}}=197.12, \mathrm{df}=70, P<.0001\right)$. Of the 71 replicated $G$-tests performed, 15 were significant because of positive deviations from the expected 140:700 ratio and three because of negative deviations. These results confirm that the occurrence of cooperatively breeding species among genera does not fit the null expectation (see App. A).

A regression of the number of cooperative breeders within each of 71 polytypic genera $\left(N_{\mathrm{O}}\right)$ on the total number of species in each genus $\left(N_{\mathrm{S}}\right)$ illustrates this 


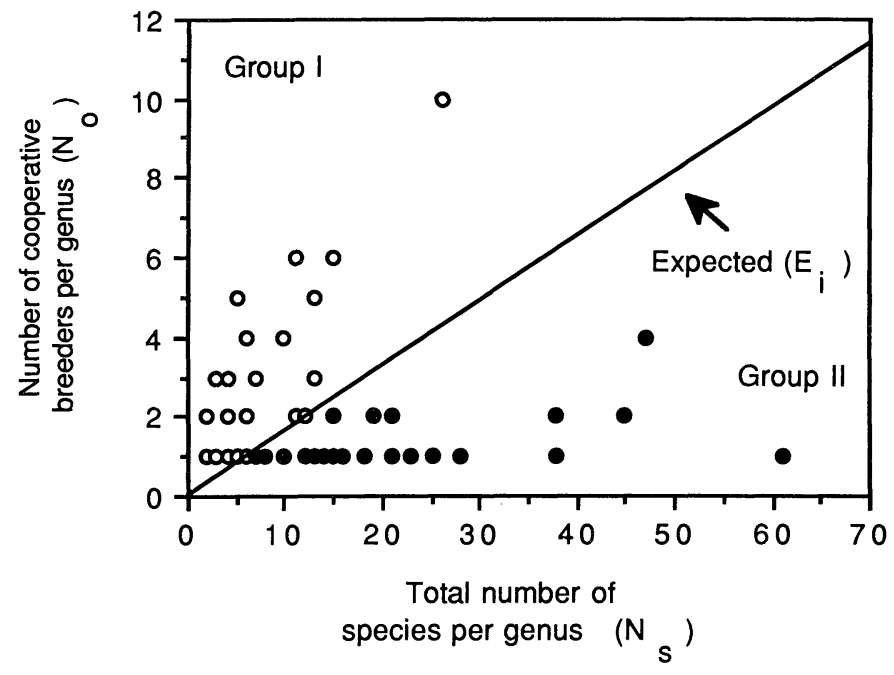

FIG. 2.-Regression of the number of cooperative breeders per genus on the total number of species in 71 passerine genera. Solid line indicates the slope expected if the number of cooperative breeders per genus were proportional to genus size. Group I points are those lying above the line $(N=43)$; Group II points are those lying below $(N=28)$.

point (fig. 2). The line indicating a direct dependence of the number of cooperative species on genus size suggests dividing the points into two groups, one showing more cooperative breeders than expected (Group I, $N=43$, above and to the left), the other showing fewer than expected (Group II, $N=28$, on the line or below and to the right). All 71 points together showed no significant relationship $\left(F=0.95\right.$, df $\left.=69, r^{2}=0.01, P>.1\right)$, but the regressions were significant for each group separately (Group I: $F=79.44$, df $=41, r^{2}=0.66, P<.0001$; Group II: $F=6.058$, df $\left.=26, r^{2}=0.19, P<.01\right)$. With the 21 small genera $(\leq 6$ species) containing a single cooperative breeder and/or the outlying babbler genus (Turdoides) removed from Group I, the regressions were still significant $(P<$ $.05)$. An ANCOVA indicated that the two groups possessed significantly different slopes $(F=79.7$, df $=1, P<.0001)$, both of which also differed from that of random expectation (Group I: $t=4.44$, df $=41, P<.001$; Group II: $t=-16.14$, df $=26, P<.001)$.

The distribution of the proportion $P_{\mathrm{C}}\left(=N_{\mathrm{O}} / N_{\mathrm{S}}\right)$ of each genus that is cooperative is summarized in Appendix A. The significance of the number of genera rich in cooperative breeders $\left(P_{\mathrm{C}}=0.45-0.95\right)$ was tested against six simulations of a random distribution of $\mathrm{CB}$ (fig. 3; table 1). In all cases except $P_{\mathrm{C}}=0.45$, the observed number of genera showing a proportion $P_{\mathrm{C}}$ or higher was significantly greater than that indicated in the simulations. Of course, there are numerous null models against which the data could be tested; for example, had we distributed the 140 cooperatively breeding species across all perching bird genera (regardless of whether they contained at least one cooperative breeder), the clash of the data with this random model would have been more striking. 

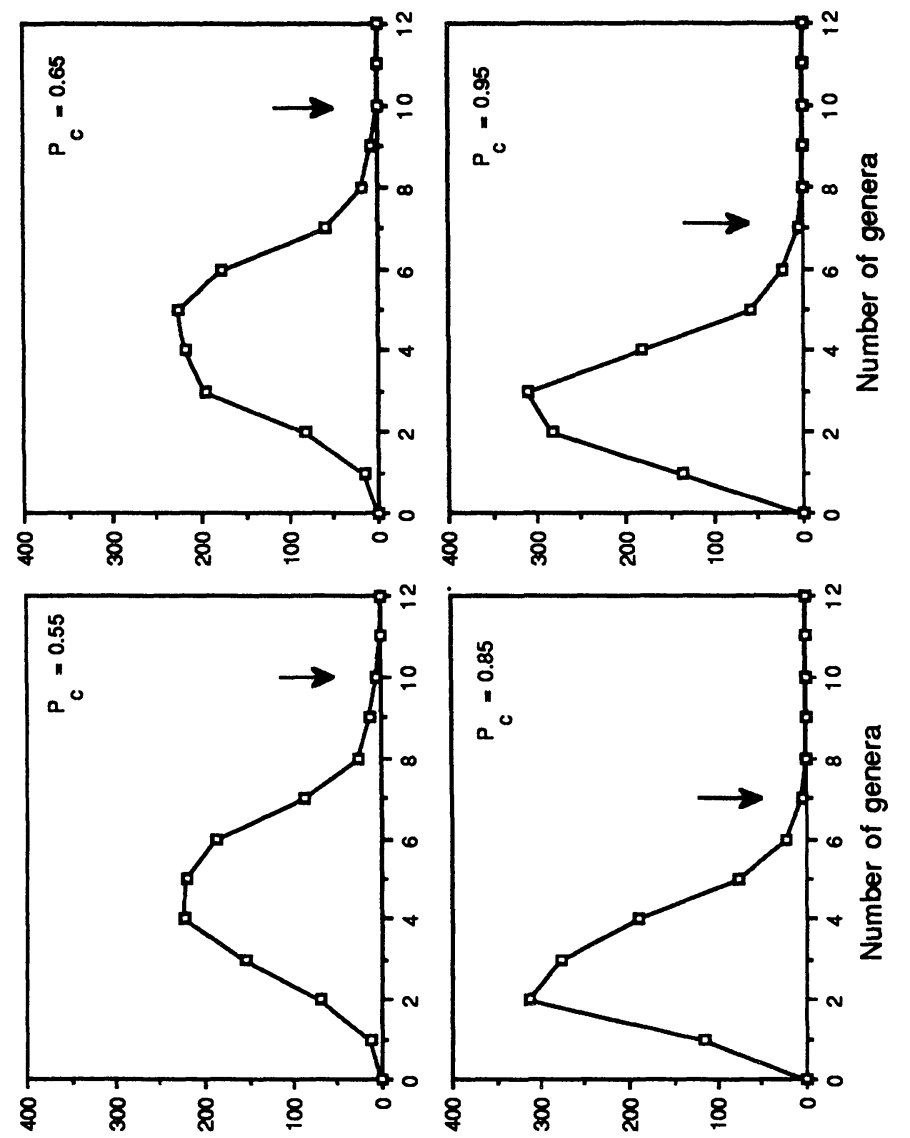

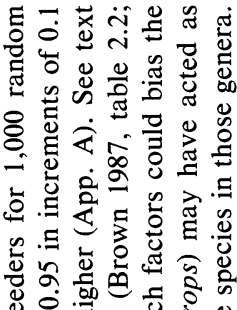

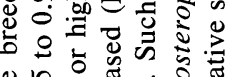

告

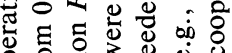

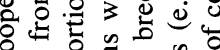

$8 \approx 0 \%$

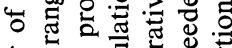

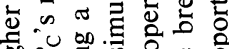

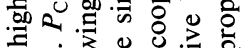

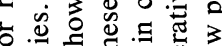

U क छ

2.

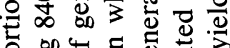

응.

๙

๙

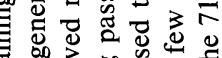

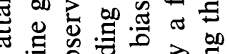

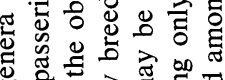

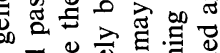
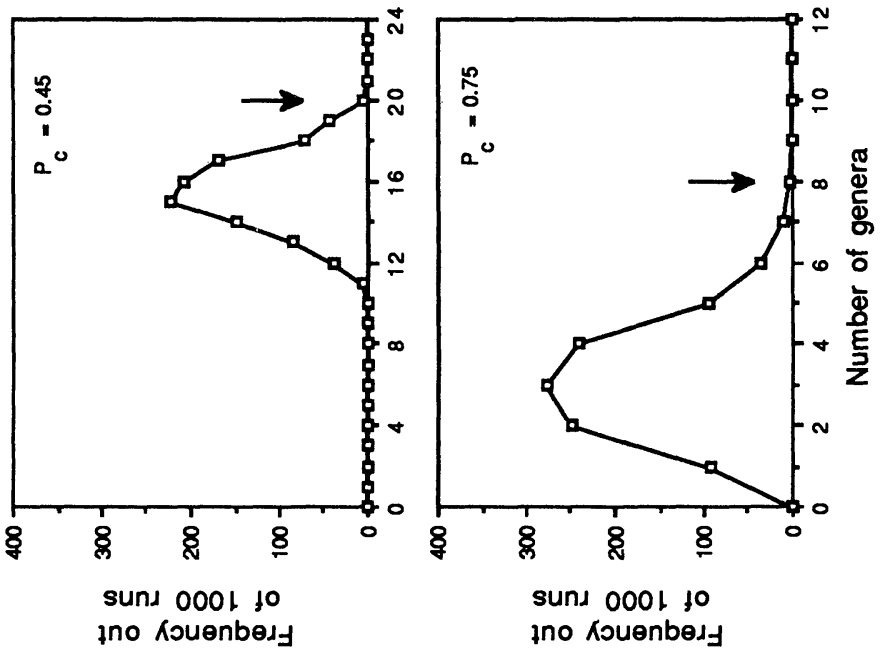

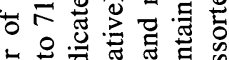

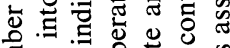

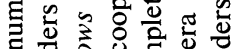
व ڤ

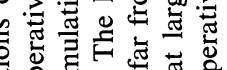
음

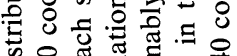

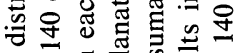

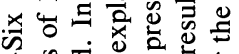

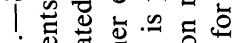

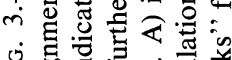

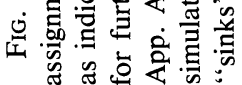
tno xouenbeds 
TABLE 1

Simulation Analysis of the Number of Genera Rich in Cooperative Breeders

\begin{tabular}{lccccc}
\hline \hline & \multicolumn{5}{c}{ Number OF Genera } \\
\cline { 2 - 5 } SPECIFIED & \multicolumn{5}{c}{ EXPECTED } \\
\cline { 2 - 5 } Proportion $\left(P_{\mathrm{C}}\right)$ & Average & Median & By Chance & OBSERVED & $\begin{array}{c}\text { UNEXPLAINED } \\
\text { BY SIMULA TION }\end{array}$ \\
\cline { 2 - 6 } .45 & 15.52 & 15 & 20 & 20 & 0 \\
.55 & 3.72 & 4 & 7 & $10^{*}$ & 3 \\
.65 & 3.48 & 3 & 7 & $10^{*}$ & 3 \\
.75 & 2.15 & 2 & 5 & $8^{*}$ & 3 \\
.85 & 1.89 & 2 & 5 & $7^{*}$ & 2 \\
.95 & 1.84 & 2 & 5 & $7^{*}$ & 2 \\
\hline
\end{tabular}

* Significance at $P>.01$. For example, the number of simulation runs out of 1,000 in which 10 genera showed $P_{\mathrm{C}} \geq .55$ was five, which indicates a probability of less than one in 100 that this number would be observed by chance.

\section{Phylogenetic Analyses}

Suitable phylogenies or descriptions of relationship were available for all species within seven monophyletic groups (genera or families) that were largely cooperative.

1. Australian treecreepers (Climacteris). Individuals within four of the six species of Australian tree creepers have been documented to breed cooperatively, albeit facultatively (Noske 1980). The analysis of Keast (1961) suggests that three of the cooperatively breeding species fall into one clade (fig. $4 A$ ). Climacteris affinis is hypothesized to have secondarily lost CB. Thus, $\mathrm{CB}$ may well have evolved only once in this genus, despite there being four cooperatively breeding species in the group.

2. Fairy wrens (Malurus). Brown's (1987) compilation lists six species of cooperatively breeding Australian fairy wrens (Rowley 1965; reviewed in Rowley 1976), but it is probable that every species of Malurus is a cooperative breeder, the New Guinea species being understudied (Cooper 1969; Schodde 1982b; Tidemann 1986; I. Rowley, E. Russell, R. B. Payne, D. Schodde, personal communication). Species of related emu wrens (Stipiturus) and grasswrens (Amytornis) are probably also cooperative breeders (E. Russell, personal communication; see fig. 4 legend). In lieu of this lack of confirmatory data on New Guinea species, we depict the origin of $\mathrm{CB}$ on the branch leading to the primarily Australian clade (fig. $4 B$ ).

3. New World wrens (Campylorhynchus). In addition to the six cooperative breeders mentioned in Brown's (1987) list, CB is also known in Campylorhynchus rufinucha and C. turdinus (Selander 1964; Rabenold 1990). The most parsimonious distribution of CB on the phenogram of Selander (1964) suggests that three independent derivations of $\mathrm{CB}$ can explain its presence in the eight known cooperatively breeding wren species. 


\section{A, Australian tree creepers (Climacterls)}

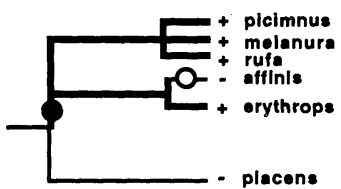

B, Australian fairy wrens (Malurus)

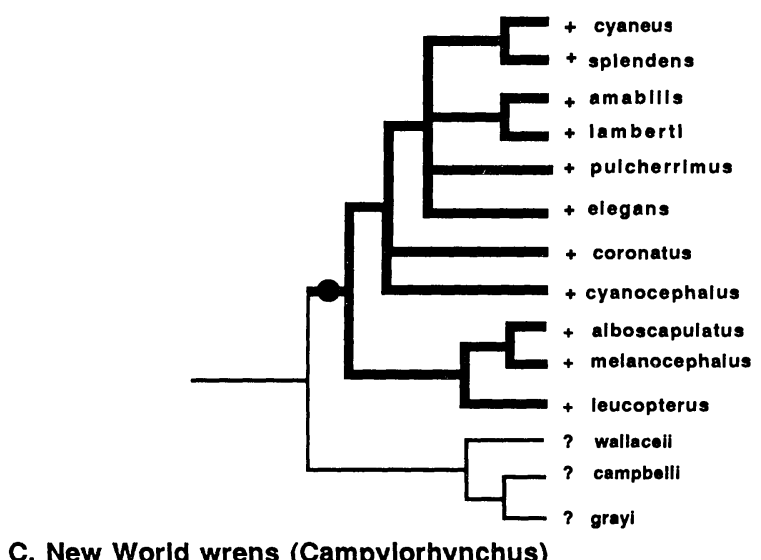

C, New World wrens (Campylorhynchus)

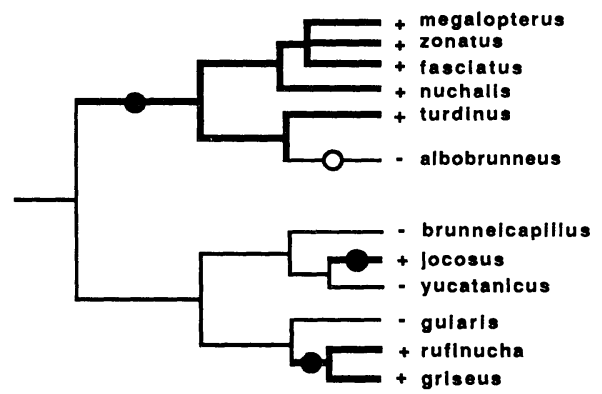

FIG. 4.-Phylogenetic hypotheses for three genera rich in cooperative breeders. In each phylogeny a plus sign signifies a cooperatively breeding species at that tip, and a minus sign signifies lack of cooperative breeding. Question marks indicate uncertainty given present data. Open and solid circles indicate, respectively, inferred loss and gain of cooperative breeding along that branch by the parsimony criterion (Maddison et al. 1984); boldface lines indicate lineages along which cooperative breeding is hypothesized to be present, and thin lines indicate lack of cooperative breeding. In each case, if there were two equally parsimonious reconstructions of $\mathrm{CB}$, the one in which $\mathrm{CB}$ originated earlier in the tree was illustrated (see text); reconstructions on trees that possessed polytomies (unresolved branching patterns) were tested on resolved trees compatible with the unresolved one. A, Climacteris as outlined in Keast (1961); $B$, Tentative phylogenetic hypothesis of Malurus based on plumage and morphological characters (Cracraft 1986; J. Cracraft and J. Ford, personal communication) and using the species designations of Schodde (1982b). It is probable that all species of Malurus and related species of emu wrens (Stipiturus) and grass-wrens (Amytornis) are cooperative breeders (I. Rowley and E. Russell, personal communication), which implies that $\mathrm{CB}$ in this group could have originated up to 15 million years ago, based on DNA evidence (Sibley and Ahlquist 1985) and the dating correction of Helm-Bychowski and Wilson (1986). C, Campylorhynchus after Selander (1964). None of the trees in figs. 4-8 have been statistically tested against alternate arrangements, and the ways in which the DNA hybridization method was applied to songbirds have been questioned (Helm-Bychowski and Wilson 1986; Cracraft 1987; Sarich et al. 1989; Wilson 1989). 
4. Scrub jays (Aphelocoma) and other New World jays. Cooperative breeding is likely shared primitively by jay species in the genus Aphelocoma (fig. $5 A$ ), which has been intensively studied in both ecological (Brown 1974; Woolfenden and Fitzpatrick 1984) and historical contexts (Pitelka 1951; Hardy 1961, 1969, 1974; Brown and Horvath 1989; Peterson 1991a, 1991b). Thus, helping and sociality may have arisen once and secondarily were lost in Cyanocitta and western scrub jays (Aphelocoma c. coerulescens; fig. $5 \mathrm{~A}$ and $B$; see legend).

5. Butcherbirds and allies (Cracticidae). A phylogenetic tree based on DNA hybridization data for the closely related Australian magpies, butcherbirds, and allies (Sibley and Ahlquist 1985) suggests that CB may have arisen in the common ancestor to these genera (not shown). The lower frequency and plasticity of helping in butcherbirds (Cracticus; two of four species) and wood swallows (Artamus; four of 10) weakens the idea that CB originated primitively for these genera, but the remaining species in these genera may be understudied.

6. Australian songbirds. The novel suggestion (Sibley and Ahlquist 1985; Sibley et al. 1988) that many endemic Australo-Papuan genera may belong to a large monophyletic radiation raises the possibility that $\mathrm{CB}$ may have originated in the common ancestors of long-separated genera and families, and not independently acquired in each lineage (Russell 1989; Heinsohn 1990; fig. $6 A$ and $B$ ), although the particular sequence of gains and losses of $\mathrm{CB}$ may require refinement given competing phylogenetic hypotheses (Edwards et al. 1991) and recent discoveries of CB in other Australian species.

Phylogenetic tests of ecological scenarios.-Data on foraging stratum, diet, seasonality, aridity of habitat, and sedentariness were compiled for three groups of Australo-Papuan birds in a manner similar to that of Ford et al. (1988). However, only the first two analyses include species that were represented in the list of Ford et al. (1988).

For fairy wrens (Malurus), foraging stratum and seasonality of habitat show complex patterns of origin and loss that do not correlate well with $\mathrm{CB}$ when viewed phylogenetically (fig. 7; cf. fig. $1 C$ ). Sedentariness and insectivory are primitively shared with emu wrens (Stipiturus). Cooperative breeding may have arisen in the ancestor invading arid habitats (fig. 1A), although reconstructions of both traits are ambiguous. The relationship between the origins of $\mathrm{CB}$ and other factors is difficult to evaluate now because little is known about helping in emu wrens and grass-wrens (Amytornis; not shown).

Depending on the reconstruction (fig. 8), the origin of CB in Australian robins (Eopsaltria) and allies may have coincided with invasion of seasonal habitats. All traits except seasonality showed a high degree of lineage specificity. Insectivory, ground foraging, sedentariness, and wet habitats are primitively shared by robins and their noncommunal relatives, bearing relationships to $\mathrm{CB}$ similar to those depicted in figure $1 B$. 


\section{A, Scrub Jays (Aphelocoma)}

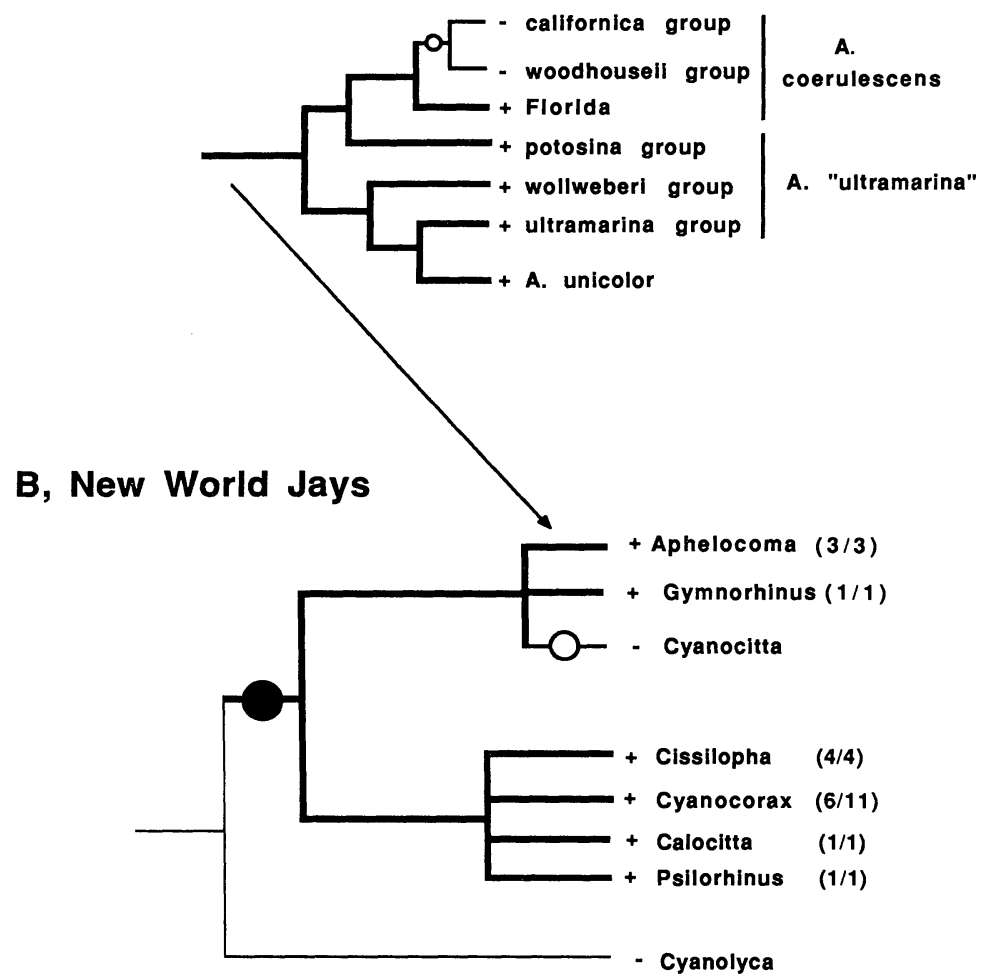

FIg. 5.-Phylogenetic reconstructions of CB in New World jays. See legend to fig. 4 for explanation. A, Aphelocoma, following Peterson (1991, fig. 7A). Hardy (1961) argued that territoriality was primitive for all Aphelocoma taxa and that cooperative breeding was derived in A. c. coerulescens and A. ultramarina. Pitelka (1951, p. 358) and J. L. Brown (unpublished data) suggest that $A$. unicolor is in fact social and probably a cooperative breeder. $B$, Phylogeny of genera of New World jays based on electrophoretic data (T. Peterson, personal communication). Numbers in parentheses after certain genera indicate the number of cooperative breeders/total number of species in that genus (otherwise groups have no cooperative breeders listed in table 2.2 of Brown 1987, although some Cyanolyca are probably cooperative breeders [T. Peterson, personal communication]). Regardless of the position of Cyanocitta in $A$, sociality among genera has been lost a maximum of two times since the origin of the jays. It is likely that more than the six Cyanocorax species listed by Brown (1987) are social (F. Pitelka, personal communication), thereby corroborating the primitiveness of helping behavior in this genus, even if CB is not primitive for Aphelocoma, as depicted in $B$. This pattern would suggest that sociality has persisted for nearly 10 million years, incorporating the dating correction on the data of Sibley and Ahlquist (1985) suggested by Helm-Bychowski and Wilson (1986). 


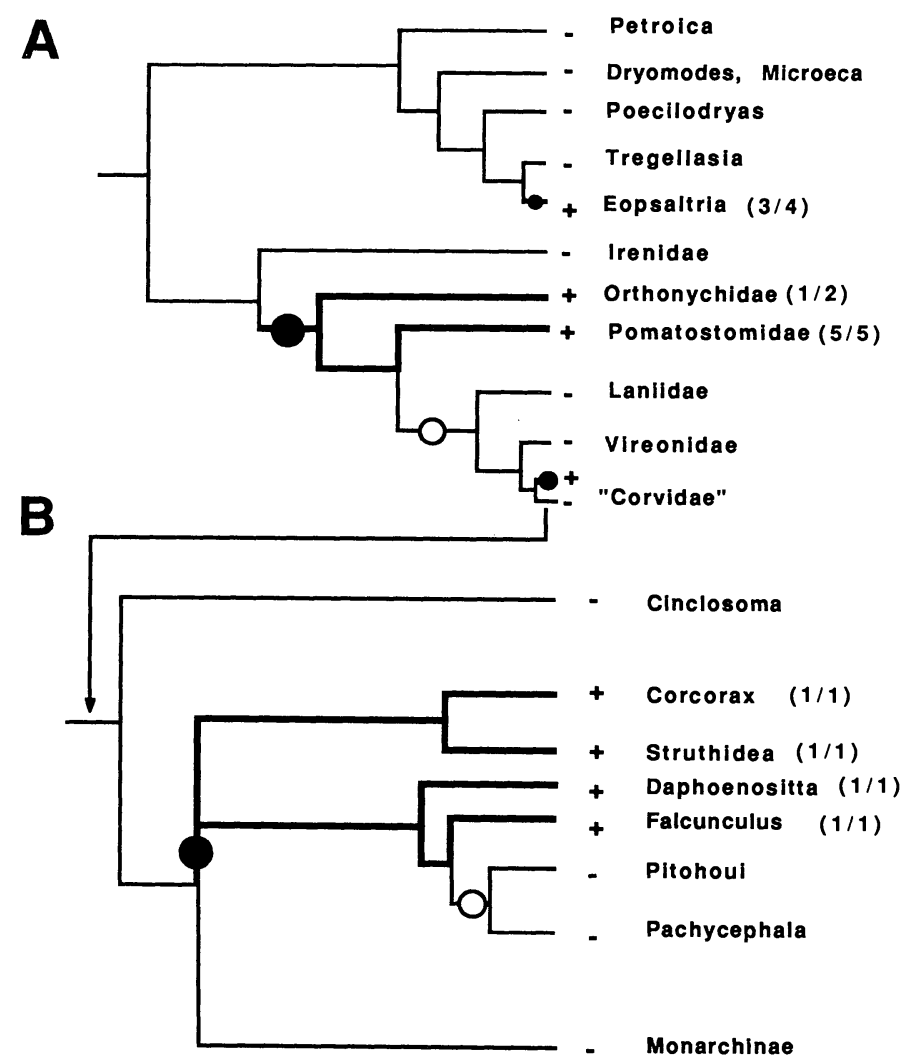

FIG. 6.-Phylogenetic hypothesis for two sections of the superfamily "Corvoidea" (after Sibley and Ahlquist 1985). Explanation is as in figs. 4 and 5. A, The branch of the "Corvidae" labeled as cooperative is meant to denote the New World jays of fig. 5, and not to indicate that this branch is the sister group to the rest of the "Corvidae." $B$, A continuation of one of the branches in fig. 5A leading to the "Corvidae" (sensu Sibley and Alhquist 1985; see arrow). This scenario involves only one origin of cooperative breeding, which may have occurred up to 30 million years ago, based on DNA evidence (Sibley and Ahlquist 1985) and the dating correction of Helm-Bychowski and Wilson (1986). Cooperative breeding is not hypothesized to be primitive for the "Corvidae" (sensu Sibley and Ahlquist 1985) but to have arisen independently on various branches of the tree as shown.

In Australian babblers (Pomatostomus), CB probably originated in rain forests before the arid interior of Australia was colonized (Schodde 1982a); through this change in selective regime, all descendant species remained cooperative breeders (fig. 9). The phylogenetic persistence of $\mathrm{CB}$ thus matches the scenario in figure $1 C$.

Other traits that have been considered important in promoting $\mathrm{CB}$, such as diet breadth and predation in New World jays (Brown 1974; Woolfenden and Fitzpatrick 1984), should be checked for their presence in appropriate outgroups; 


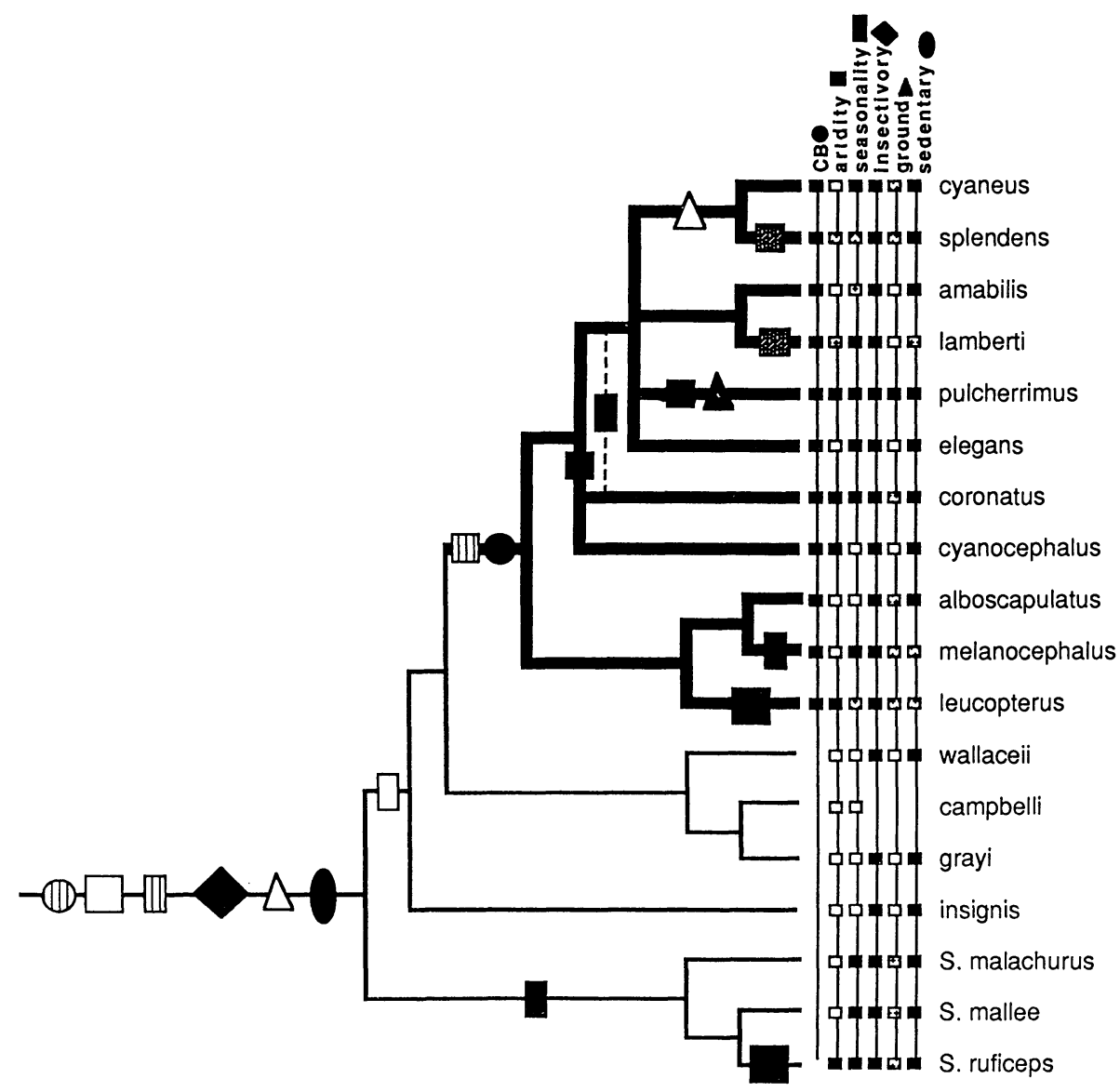

FIG. 7.-Possible relationships between the onset of various ecological and demographic variables and the origin of CB in Australian fairy wrens (Malurus). In figs. 7-9, solid, white, and stippled squares under the six traits listed at the top right indicate the presence, absence, or polymorphism, respectively, for the trait in each taxon. Absence of a square for a given taxon means the data were unavailable or unconfirmed. On the trees, open and solid circles and thick branches designate presence or absence of CB as in figs. 4-6; solid, open, stippled, or striped patterns of the five other shapes explained in the figure represent presence, absence, polymorphisms, or ambiguity of state, respectively, for that trait on that branch. At the bottom of the tree shapes and their patterns indicate the ancestral state on that branch; establishing the origin of these traits on these branches would require further outgroups. Character assignments in this and the following two figures were found in Rand and Gilliard (1967), Schodde (1982b), Blakers et al. (1984), Beehler et al. (1986), Schodde and Tidemann (1986), R. Schodde (personal communication), J. Diamond (personal communication), and E. Russell (personal communication). The states for seasonality were assigned based on whether the species' range fell within, outside of, or overlapped the $50 \%$ seasonal growth index contour depicted by fig. 8 of Nix (1976). Migratory behavior was indicated only when there was evidence in the literature for substantial and repeated seasonal movements of individuals to new areas. Species' habitats were scored as arid if they fell largely within the 200- to 400-mm summer rainfall contour line of fig. $16 a$ in Blakers et al. (1984). The phylogenetic hypothesis of Malurus uses the species designations of Schodde (1982b) and the tenta- 


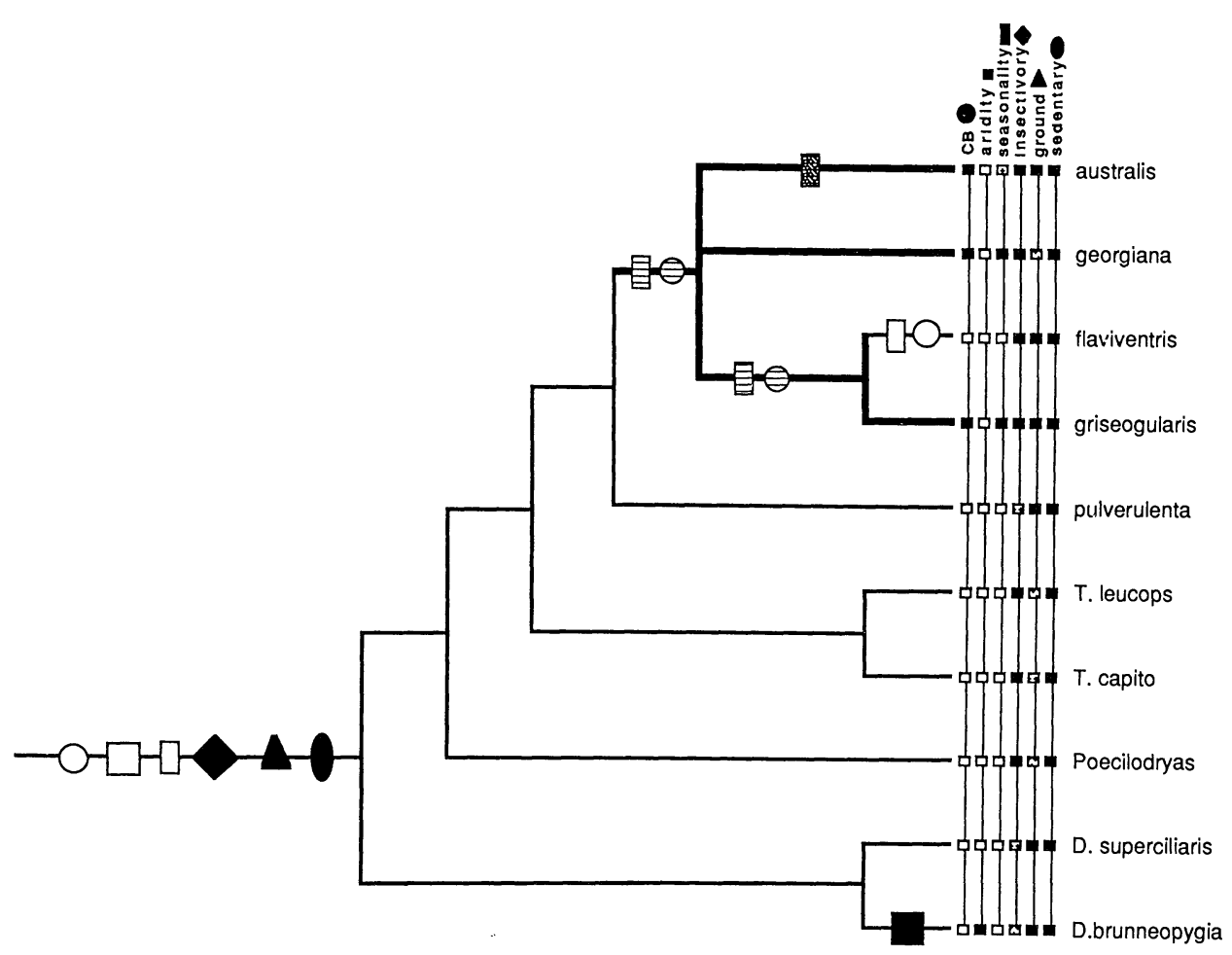

Fig. 8.-Possible relationships between the onset of various ecological and demographic variables and the origin of $\mathrm{CB}$ in Australian robins (Eopsaltria). Shapes and their patterns are described in the legend to fig. 7. Only two possible reconstructions of $\mathrm{CB}$ and seasonality are depicted here; they depend on the exact affinities of E. georgiana. Relationships within Eopsaltria are summarized in Ford (1979); generic phylogeny follows Sibley and Ahlquist (1985). T, Tregellasia; D, Dryomodes. Species within Poecilodryas are considered similar for all of the characteristics, except for foraging stratum, which is considered "polymorphic" (J. Diamond and D. Schodde, personal communication).

for example, it is likely that a wide diet breadth evolved early in the corvid lineage (Goodwin 1976), long before the emergence of sociality in various descendant lineages (fig. $1 B$ ). Although this scenario does not negate the potential importance of diet breadth for $\mathrm{CB}$, it does clarify the temporal relationship between these two variables and suggest that other factors were ultimately involved, as discussed by Brown (1974).

tive topology of J. Cracraft and J. Ford (personal communication), with emu wrens (Stipiturus) as the closest outgroup (Sibley and Ahlquist 1985). It is possible that CB is present in species of Stipiturus and grass-wrens (Amytornis) as well (not shown; E. Russell, personal communication); for this reason the state of $\mathrm{CB}$ at the bottom is indicated as ambiguous. The dashed line connecting Malurus coronatus and the ancestor of Malurus cyaneus through Malurus elegans indicates that the reconstruction of seasonality conflicts with that of aridity for these taxa. Sipodotus wallaceii and Clytomyias insignis (Schodde 1982b) are indicated simply as insignis and wallaceii, respectively. 


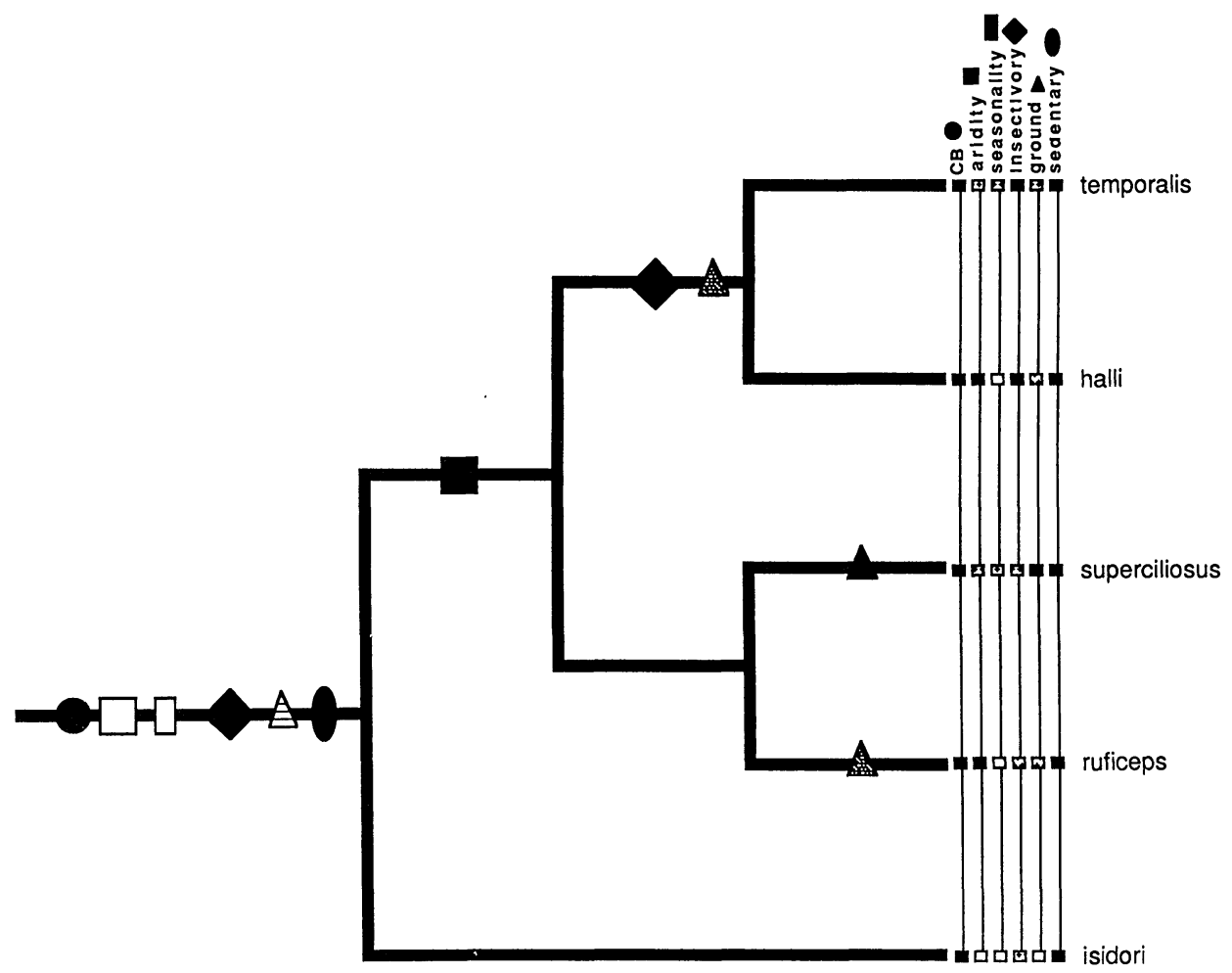

FIG. 9.-Possible relationship between changes in various ecological and demographic variables and $\mathrm{CB}$ in Australo-Papuan babblers (Pomatostomus). Nonarid habitat and aboveground foraging are assumed to be the ancestral states for these traits (Schodde 1982a). Because of polymorphism for foraging stratum in most of the taxa, the first instance of ground foraging cannot be determined unambiguously. Pomatostomus ruficeps is known to be a cooperative breeder (Boehm 1974). The phylogeny is from mitochondrial DNA data in Edwards and Wilson (1990). Close outgroups to Pomatostomus are uncertain (Sibley and Ahlquist 1985; Edwards et al. 1991).

\section{DISCUSSION}

Our main goal in this article is to return attention to and illustrate the importance of considering hypotheses on the evolution of CB in explicitly phylogenetic contexts, an approach that can be integrated into both comparative surveys of $\mathrm{CB}$ and ecological and behavioral studies of individual species or populations. This suggestion arises from a concern that scenarios for the evolution of $\mathrm{CB}$ in any one species can be compromised by biological correlations of traits in that species with those of related species and from the observation that in many cases CB or its life-history components may have arisen in common ancestors experiencing selective pressures different from those molding current populations.

We have confirmed that the taxonomic distribution of $\mathrm{CB}$ in perching birds is significantly nonrandom, a pattern that may hold true for many nonpasserine 
TABLE 2

Examples of the Number of Times Cooperative Breeding Is Hypothesized to Have Arisen with and without the Assumption of a Phylogeny

\begin{tabular}{|c|c|c|c|c|}
\hline \multirow[b]{2}{*}{ TAXON } & \multicolumn{2}{|c|}{ NumbER OF ORIGINS } & \multicolumn{2}{|c|}{$\begin{array}{l}\text { Percentage } \\
\text { Cooperative }\end{array}$} \\
\hline & $\begin{array}{l}\text { If Each Species } \\
\text { Independent }\end{array}$ & $\begin{array}{l}\text { With Phylogenetic } \\
\text { Correction }\end{array}$ & Taxon & Clade* \\
\hline Nuthatches (Sitta) & 2 & 1 & 9 & 100 \\
\hline Fairy wrens (Malurus) & $\sim 11 \dagger$ & 1 & $100 \dagger$ & $100 \dagger$ \\
\hline New World wrens (Campylorhynchus) & 8 & 3 & 50 & 50 \\
\hline Australian treecreepers (Climacteris) & 4 & 1 & 67 & 80 \\
\hline Australian babblers (Pomatostomus) & 5 & 1 & 100 & 100 \\
\hline Scrub jays (Aphelocoma) & 3 & 1 & 100 & 100 \\
\hline New World jays & 16 & 1 & 53 & 70 \\
\hline
\end{tabular}

* Percentage of clade calculated as the number of cooperative species in the taxon divided by the minimum number of species in the clade defined by the two most divergent cooperative species in the taxon.

+ See text.

groups as well (e.g., woodpeckers, sister taxa Melanerpes formicivorus and Melanerpes cruentatus and other species) (Short 1982; W. Koenig, personal communication), bee eaters (Merops; six out of 21 species cooperative), and anis (Crotophaginae) (Davis 1942). This conciusion is corroborated by phylogenetic analyses (figs. 4-6) suggesting that in many cases $\mathrm{CB}$ or some trait strongly correlated with $\mathrm{CB}$ arose prior to the origin of the taxa in which we observe $\mathrm{CB}$ today. Simultaneous mapping of the phylogenetic distribution of $\mathrm{CB}$ and various ecological variables suggests a variety of temporal relationships between the invasion of particular ecological or demographic regimes and the origin of $\mathrm{CB}$. Clearly the list of $\mathrm{CB}$ in passerines is constantly growing, and our estimates of the degree to which it is nonrandomly distributed and our depiction of its distribution on phylogenies will require revision. Regardless of the basis and amount of phylogenetic clustering, a phylogenetic perspective suggests that $\mathrm{CB}$ or factors promoting it have arisen fewer times than would be expected had each species evolved it independently, particularly in species belonging to genera rich in cooperative breeders (Group I, fig. 1; table 2).

\section{HISTORICAL AND ENVIRONMENTAL CONTINGENCY: ALTERNATIVE OR COMPLEMENTARY HYPOTHESES?}

\section{Behavioral Plasticity: Helping as an Environmentally Contingent Expression of Phylogenetically Conservative Traits}

Of the many obstacles to meaningful reconstruction of character evolution using phylogenetic trees (e.g., missing taxa, inappropriateness of the parsimony method, incorrect phylogenies, incomplete character data; reviewed in Brooks and McLennan 1990; Harvey and Pagel 1991; Martins and Garland 1991; Wilson et al. 1991), we consider temporal plasticity and geographical variation in helping 
and $\mathrm{CB}$ to be the most serious. Although some sort of categorization of species as $\mathrm{CB}$ or non- $\mathrm{CB}$ is usually required for surveys such as ours, the evidence for context-specific plasticity and seasonal variation in many aspects of CB (see, e.g., Emlen and Wrege 1989; Curry and Grant 1990) may render our interpretations more appropriate for "obligate" than for "facultative" cooperative breeders (Ford 1989) (Group I, fig. 1; App. A).

Phylogenetic bias in behaviors and life-history attributes promoting $C B$.- However, there is a general consensus that a number of specific behaviors may "set the stage" for CB and helping (Brown 1974, p. 77; Jamieson 1989). The results in this article are consistent with there being a strong phylogenetic bias to any of the social, behavioral, demographic, or physiological factors that predispose nonbreeders to help. Candidate behaviors in communal breeders include all those for which the occurrence with communal breeding and helping is frequent-sedentariness, delayed breeding, reduced dispersal, parental "stimulusresponse'" behavior in young (Jamieson and Craig 1987; Jamieson 1989), parental facilitation and tolerance of young, kin recognition mechanisms, or capacity for imitative learning (Wilson 1989).

Because the expression of such traits is known to be modified qualitatively by even slight changes in the physical, social, or demographic environment (Stacey and Bock 1978; Tidemann 1986; Emlen and Wrege 1988, 1989; Burke et al. 1989; Rowley et al. 1989; Curry and Grant 1990; Pruett-Jones and Lewis 1990; Emlen 1991; Emlen et al. 1991), then this view is not at variance with but complementary to observations of predictable geographical, temporal, and context-specific variation in helping, dispersal, or CB itself (cf. West-Eberhard 1987). The perspective afforded by a focus on shared components of $\mathrm{CB}$ not only helps identify aspects of extant CB systems that were present in common ancestors (cf. Baroni Urbani 1989; I. Jamieson, unpublished manuscript) but also further qualifies arguments for the evolution of components of CB largely through current ecological or social constraints (Koenig and Pitelka 1981; Emlen 1982). If the diversity of mating systems and "routes" toward CB in particular groups (Brown 1974, 1987 [table 2.2]) is too great for them to be considered "homologous" (i.e., derived from one another by descent with modification) (Atz 1970), then phylogenetic analysis of such systems would be inappropriate.

Relationship of CB to extrinsic factors.-Ideally, geological data on past environments should corroborate phylogenetic reconstructions of ecological regimes. Thus, our reconstructions of aridity agree with the prevailing view (Schodde $1982 a$ ) that many endemic Australian passerine groups originated in rain forest environments. The Miocene origin of $\mathrm{CB}$ in some lineages clearly predates the Pleistocene environments in which it is found today, persisting despite environmental fluctuations (Russell 1989; Heinsohn et al. 1990) (figs. 7-9; see below). The finding that many cooperatively breeding species may ancestrally share environments with noncommunal relatives does not negate the potential importance of these ancestral environments for the evolution of $\mathrm{CB}$ but questions their status as "correlates" of CB, since many taxa in the monophyletic groups in which CB is found may ancestrally share the hypothesized selective regime yet not evolve $\mathrm{CB}$ (fig. $1 B$ ). Of course, an interaction of multiple ecological and demographic 
variables not addressed by this or other surveys may ultimately be required for the emergence of helping in some lineages. This analysis invites a phylogenetic confirmation of those factors identified in noncomparative studies as well as a search for new factors arising on the same branches of trees as CB. Importantly, the inability of many authors to detect strong correlations between ecological variables and the geographical distribution of CB (Dow 1980; Brown 1987, p. 36) could have been obscured because these studies were not conducted in phylogenetic contexts (Type II error) (Gittleman and Kot 1990).

\section{Phylogenetic Inertia}

Most systematic studies assume that clustering of characters is due to sharedderived traits, which manifest themselves at higher taxonomic levels by their widespread distribution among descendants from common ancestors and result from common underlying genetic or developmental mechanisms. "Phylogenetic inertia" occurs when traits persist in lineages after the cessation of selective forces thought to have produced or maintained them or through episodes of selectively important environmental oscillations (Wilson 1975, p. 32; Greene and Burghardt 1978; Janzen and Martin 1982; Felsenstein 1985; Greene 1986; Burt 1989; Diamond 1990 and references therein); it implies a tendency for traits to resist change despite environmental perturbations. Phylogenetic inertia has been implicated or invoked in several studies of social behavior in diverse taxonomic groups, often because of taxonomic clustering or extreme age (e.g., CB in birds: Fry 1977; African mole rats: Honeycutt et al. 1987 [but see Honeycutt et al. 1990; Allard and Honeycutt 1991]; ants: Wilson 1971; butterfly larvae: Sillen-Tullberg 1988; bees: Michener and Grimaldi 1988; wasps: Carpenter 1989, Ross and Carpenter 1991) (see legends for figs. 4-6).

The group of avian genera in which such clustering and, in some cases, extreme age (legends for figs. 4-6) is inferred includes several of the best-studied cooperatively breeding species. Thus, the possibility of phylogenetic inertia of life-history traits promoting helping provides an important caveat to the assumption that $\mathrm{CB}$ necessarily reflects responses to current environmental or ecological factors. Cladistic analysis in Australian babblers (Pomatostomus) shows that CB has persisted in lineages that have nonetheless invaded novel ecological regimes (fig. 9). Fairy wrens (Malurus) also occur in a wide range of habitats, which suggests the persistence of CB despite ecological shifts (R. B. Payne, personal communication). Phylogenetic inertia of factors conducive to helping is especially plausible for such genera and is useful as a null hypothesis for their presence in species whose ancestors are suggested to be cooperative by phylogenetic analysis (I. Jamieson, personal communication). The hypothesis that phylogenetic inertia is a sufficient explanation for the presence of CB or its components in a given extant species should be rejected or complemented when further ecological evidence for its persistence is advanced, as exemplified by the argument of Marzluff and Balda (1990).

Causes of inertia in $C B$ and associated life-history traits.-Discussions of the causes of evolutionary stasis have focused primarily on morphological characters and genetic systems (Eldredge and Gould 1972; Charlesworth et al. 1982; May- 
nard Smith 1983; Slatkin 1983; Wake et al. 1983; Bull and Charnov 1985). Although discussions of constraints as trade-offs typify life-history studies, lifehistory attributes have not figured prominently in discussions of evolutionary stasis. Although many classical life-history traits seem to have low heritabilities (Price and Schluter 1991), the observation of stasis in aspects of CB implies either an endogenous, genetic component or high correlations with more stable metric traits. Substantial genetic components of diverse traits such as clutch size (van Noordwijk 1989), aspects of migratory behavior (Berthold 1991), and mating preferences (Potts et al. 1991) have been detected when sought. Some demographic traits, such as sedentariness (figs. 7-9), clutch size, and length of breeding season, show concordance with taxonomy or particular phylogenetic hypotheses (YomTov 1987; Partridge and Harvey 1988).

Stabilizing selection (e.g., by predation pressure) could be invoked to explain the maintenance of $\mathrm{CB}$ in clades characterized by single selective regimes. But since environmentally contingent traits in birds would be expected to show error rates too high to be compatible with long-term phylogenetic conservatism (Payne 1986; Prum 1990), the inference of stasis in life-history components of CB despite changes in selective regimes suggests a number of intrinsic, microevolutionary factors shaping those components:

1. Limited genetic or phenotypic variation. Although genetic variation for lifehistory strategies is generally assumed to be ubiquitous, it is also true that for many important developmental genes or protein domains there is essentially no intraspecific variation. Lack of variation is often realized at the phenotypic level. For example, individual dispersal in white-winged choughs is virtually unknown (Rowley 1978; Heinsohn 1991).

2. Pleiotrophy and genetic covariance. Correlations between components of $\mathrm{CB}$ often exceed those between any one component and the external environment. If the same genes underlie a set of life-history traits, then the evolution of one of the traits can be constrained by selection on others (Arnold 1992). Genetic correlations between two traits can cause persistence of one trait even when it is weakly selected against (Lande 1978, 1982). Both the limited variation and pleiotrophy hypotheses for the maintenance of CB have been criticized (Emlen et al. 1991; but see Jamieson 1991).

3. High correlations with metric traits. If certain metric traits are "fixed" in an ancestral species, high correlations between metric and life-history traits could cause persistence of the life-history trait (e.g., short wings and sedentariness due to weak flight) (Fairbairn and Roff 1990; Ligon 1992).

4. Functional interdependency of components of CB. If there is a dependency of juvenile survival on helping, as is sometimes found (Brown 1987, table 11.1; Koenig and Mumme 1990; Heinsohn 1991), the resulting inability of a strategy of individual breeding to invade could render CB a difficult-to-alter "'absorbing state." As age at first breeding is progressively delayed, the strength of selection for breeding early may drop below that for other traits when helping arises. If the functional dependency ('burden') (Riedl 1978; Donoghue 1989) of these other traits on helping becomes high (e.g., if mor- 
tality increases as helping drops), loss of helping entails concordant shifts in a suite of other traits, preventing easy loss and causing persistence at higher taxonomic levels. Although a functional dependency is not widely observed, this hypothesis would predict that CB would be expected to persist phylogenetically in clades containing species in which such a dependency is great.

5. Behavioral plasticity. Behavioral plasticity can effectively reduce selection on traits if it shields individuals from fluctuations in environment (Wake et al. 1983; Laland 1991). Although phylogenetically conservative life-history components of CB may not be optimal for a given species in a given environment (e.g., sedentariness in seasonal climates), the fitness consequences of helping or group living may offset these costs.

The mechanisms of stasis in some components of $\mathrm{CB}$ emerge as unsolved questions upon phylogenetic analysis. Quantitative genetic experiments (e.g., Berthold et al. 1989; Helbig 1990), although difficult to conduct, offer opportunities for measuring genetic correlations and environmental components of lifehistory attributes in cooperative breeders (Arnold 1990). A quantitative genetic perspective suggests that "ecological responses" in communal breeding systems, in which genetic thresholds are not assumed to operate, might be construed more profitably as "reaction norms,", which explicitly assume genetic thresholds and interactions with the environment (Lewontin 1974; Gray 1989; van Noordwijk 1989).

Loss of $C B$ in descendant lineages. - The loss of CB in several example phylogenies (i.e., Aphelocoma c. californica, Cyanocitta; fig. 5A and B, respectively) suggests that phylogenetic inertia alone cannot fully explain patterns of presence or absence of helping in these groups. However, pleiotropic gene action can prevent the loss of genes or genetic biases underlying a trait even after the expression of the trait is lost during evolution (Wright 1968); thus, lineages that have lost $\mathrm{CB}$ and helping may nonetheless maintain an intrinsic bias in life-history attributes to permit its reemergence. For example, breeding pairs in the noncooperatively breeding western scrub jay allow floaters to remain in their territories until the onset of breeding (Carmen 1993), one of several ancestrally retained behaviors (F. Pitelka, personal communication) that is thought to be a prerequisite to the evolution of CB.

\section{The Phylogenetic Component of Continuous Variables Associated with CB}

When trying to explain quantitative differences among cooperative breeders, dichotomizing the alternative hypotheses of phylogenetic conservatism or ecological response becomes less useful, not only because it potentially confuses different levels of analysis (Sherman 1988) but also because the question How much of each component is underlying a trait? is more appropriate (Cheverud et al. 1985; Gittleman and Kot 1990). To illustrate this, we reconstructed the ancestral values for a quantitative trait, mean group size in Australian babblers (Pomatosto$m u s$ ), and used these values to partition group size into phylogenetic and recently evolved components for individual species, assuming that group living ultimately 


\section{Australian babblers (Pomatosiomus)}

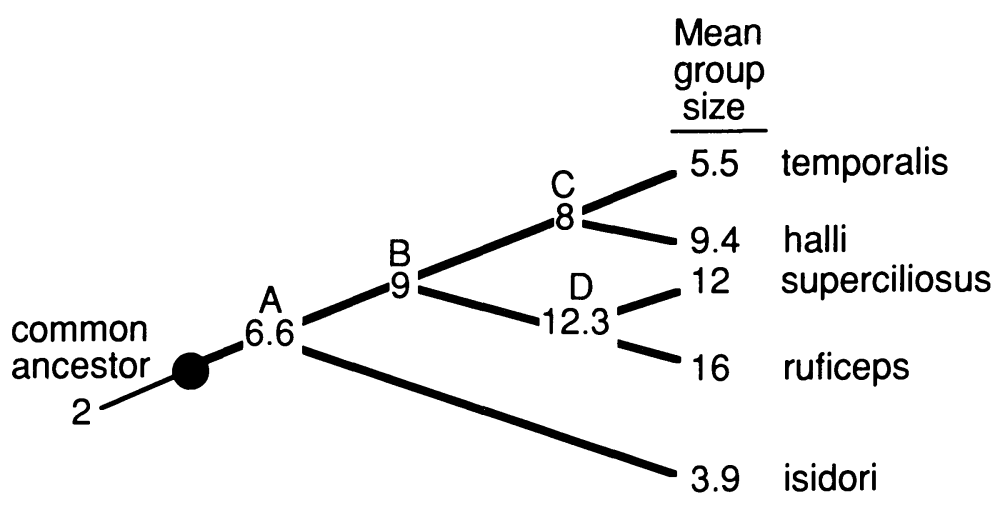

FIG. 10.-Reconstruction of mean group sizes in ancestral species of cooperatively breeding Australian babblers (Pomatostomus) using the least-squares method of Huey and Bennett (1987; see Losos 1990). The branching pattern within Pomatostomus is based on the mitochondrial DNA data of Edwards and Wilson (1990). Mean group sizes in extant species are from the following sources: P. temporalis, Brown et al. (1983); P. halli, Brown and Balda (1977); P. isidori, Bell (1982); P. superciliosus and P. ruficeps, Schodde and Tidemann (1986; midpoints of given ranges used as means). The common ancestor is assumed to be noncooperative and monogamous, a reconstruction that is as parsimonious as that depicted in fig. 6 .

arose from simple monogamous pairs (fig. 10; see Methods). Table 3 shows that this approach frequently "catches" more change in the trait (total inferred change) than would be assumed without a phylogeny (net change) and suggests that current group size in some species may have decreased from a most recent ancestor (e.g., Pomatostomus temporalis) (fig. 10). Table 3 also suggests that on the average $47 \%$ of the trait values in the tree were already present in an ancestral taxon. Alternatively, we used both the values for mean group size and a matrix of genetic differentiation among these species to employ an analysis of interspecific variation in group size using the method of Gittleman and Kot (1990). The analysis suggests that only $8 \%$ of the total interspecific variation can be attributed to phylogenetic effects (table 4). However, up to $49 \%$ of the value for group size in Pomatostomus halli can be explained solely from the values in one or more of its relatives (table 4); the mean ancestral component across species $(21 \%)$ is lower than that resulting from the ancestor reconstruction approach (table 3 ). Thus, in conjunction with the conclusion from cladistic analysis (that $\mathrm{CB}$ arose in the common ancestor of Australian babblers), these tests imply that CB in this genus is best described as a phylogenetically conserved trait that nonetheless has undergone extensive quantitative modification in each species.

We emphasize that the analyses of group size are primarily illustrative; their accuracy depends on a number of the same assumptions required for phylogenetic mapping (Gittleman and Kot 1990; Losos 1990). The fit of least-squares models to the biology of the trait in question (Martins and Garland 1991), the fact that all convergent changes in the trait (some of which could be the result of shared ecological factors) are attributed to the phylogenetic rather than the ecological 


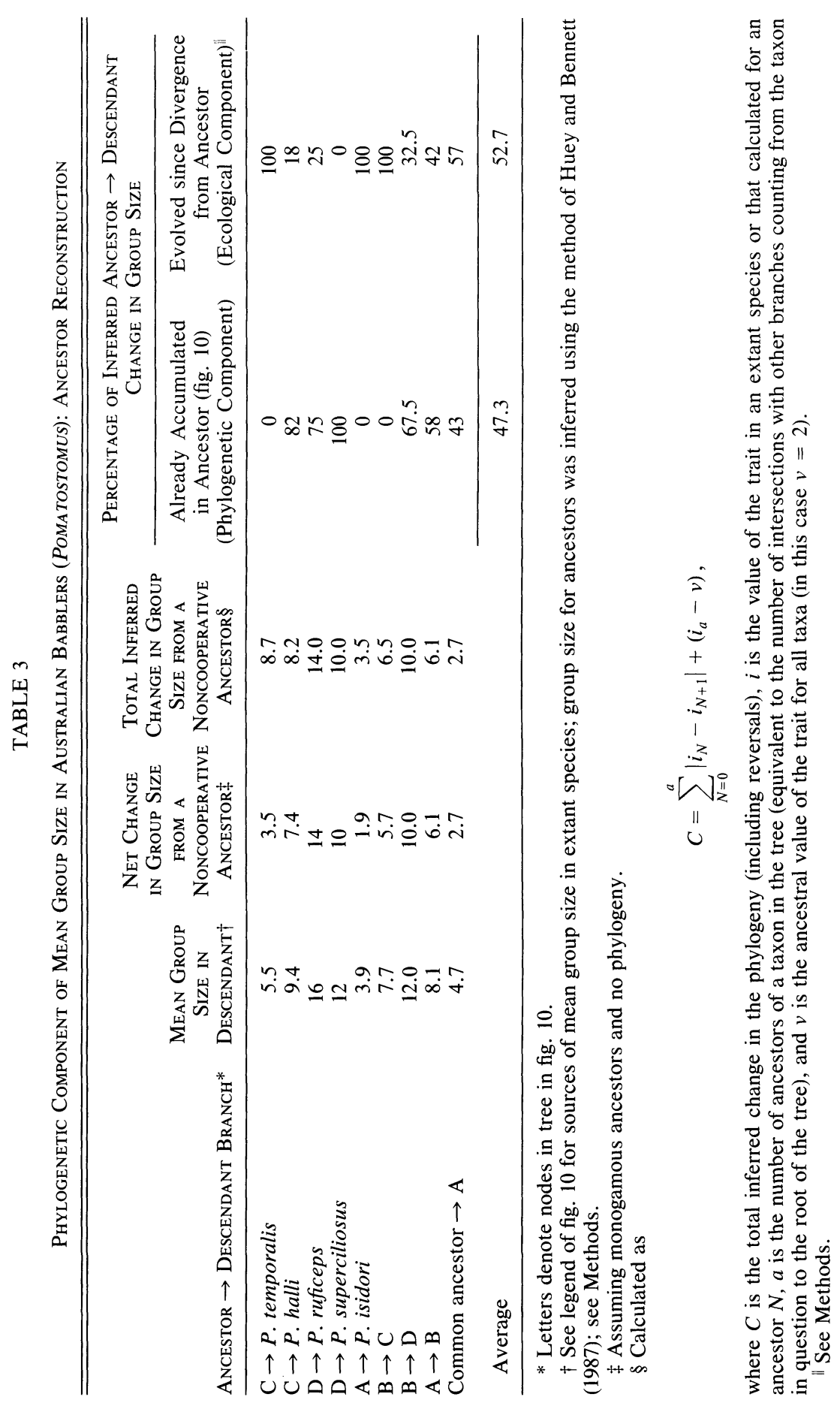


TABLE 4

Phylogenetic Component of Mean Group Size in Australian Babblers (Pomatostomus): Phylogenetic Autocorrelation

\begin{tabular}{lccc}
\hline \hline & & \multicolumn{2}{c}{$\begin{array}{c}\text { Amount of Mean Group Size } \\
\text { (\%) }\end{array}$} \\
\cline { 2 - 3 } Species & $\begin{array}{c}\text { Observed } \\
\text { Mean } \\
\text { Group Size }\left(v_{i}\right)\end{array}$ & $\begin{array}{c}\text { Explained } \\
\text { by Phylogeny }\end{array}$ & $\begin{array}{c}\text { Residual } \\
\left.\text { ("Adaptive"; } \epsilon_{i}\right)\end{array}$ \\
\hline$P$. temporalis & 5.5 & $.5(10)$ & $5.0(90)$ \\
$P$. halli & 9.4 & $4.6(49)$ & $4.8(51)$ \\
$P$. superciliosus & 16 & $.6(4)$ & $15.4(96)$ \\
$P$. ruficeps & 12 & $5.4(45)$ & $6.6(55)$ \\
$P$. isidori & 3.9 & $.1(2)$ & $3.8(98)$ \\
\multicolumn{1}{c}{ Mean percentage } & & 21 & 79 \\
Variance* & $\sigma^{2}\left(v_{i}\right)=1.25$ & & $\sigma^{2}\left(\epsilon_{i}\right)=1.15$ \\
\hline
\end{tabular}

NotE.-This analysis is based on the method outlined in Gittleman and Kot (1990) and uses a matrix of differences among the five babbler species (App. B) as well as observed values ( $v_{i}$ 's) for the continuous trait, group size. For each interspecific difference estimate in the matrix, the mean number of observed differences among individuals of the appropriate species pair for a piece of mitochondrial DNA sequence was used; these values were calculated from table 4 of Edwards and Wilson (1990). Sources of group sizes are given in the legend to fig. 10. The proportion of the total variance among species in mean group size explained by phylogeny is

$$
R^{2}=1-\frac{\sigma^{2}\left(\epsilon_{i}\right)}{\sigma^{2}\left(v_{i}\right)}=0.08
$$

* Of standardized trait values.

component, and the considerable geographical and temporal variation in group size in babblers (Counsilman 1977; S. Edwards, personal observation) clearly qualify these results. However, at least one other analysis has implicated historical effects as important determinants of group size (Brown and Horvath 1988), whose variation may be mediated in part by less labile features such as body size.

As a first step toward avoiding statistical problems due to phylogenetic correlations among species and their ancestors, these or similar approaches must be considered in intra- or interspecific studies of CB; the "ecological component", of life-history parameters, rather than the uncorrected trait values, should be used when attempting to correlate these with other variables. For example, there is a significant negative relationship between the uncorrected values for group size and body size among the five species of Australian babblers (fig. 11). When we remove the phylogenetic component of group size, the fit of a linear model drops, suggesting a more complex relationship between these two traits.

\section{Phylogeny and Cooperative Breeding-Origin and Adaptation}

Although both phylogeny and ecology are important to the taxonomic distribution and current forms of $\mathrm{CB}$, we have argued that the magnitude of the phylogenetic component and its implications for such issues as adaptation to and natural selection in current environments have been underestimated by most recent workers. As alternate hypotheses, phylogenetic and ecological scenarios to a 


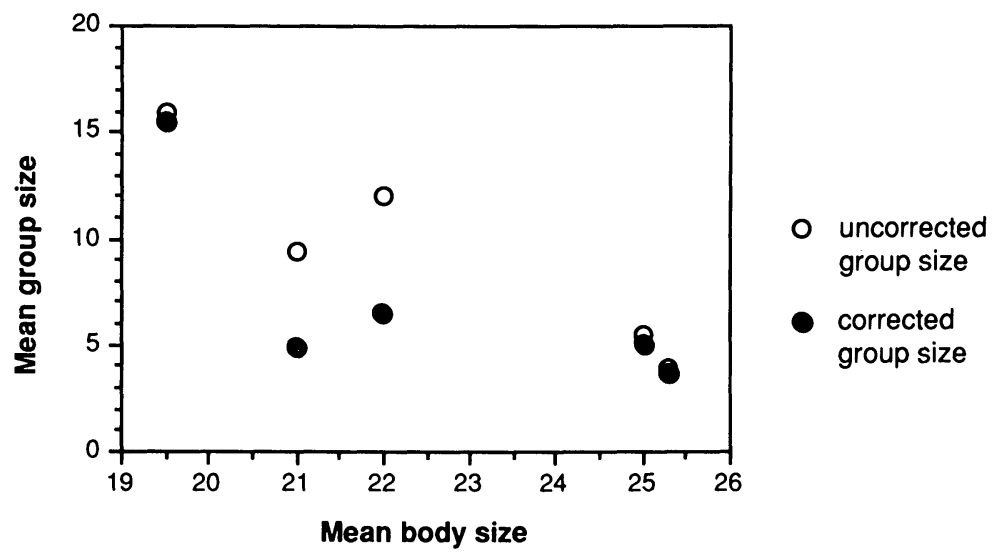

FIG. 11.-Regressions of group size on body size with (solid circle) and without (open circle) the removal of phylogenetic effects in Australian babblers (Pomatostomus). Using the uncorrected values for group size, the correlation is $r^{2}=0.87(P<.05)$. When the phylogenetic component of group size is removed using the method of Gittleman and Kot (1990) (see table 4), the correlation is $r^{2}=0.63(P>0.1)$. The autocorrelation model found no significant phylogenetic component of body size, so this trait was left uncorrected. Data on body sizes $(\mathrm{cm})$ were obtained from Beehler et al. (1986) and Schodde and Tidemann (1986) and are $P$. temporalis, 25; $P$. halli, 21; $P$. superciliosus, $19.5 ; P$. ruficeps, 22 ; and $P$. isidori, 25.3 .

certain extent address different levels of analysis (Sherman 1988); the former may identify evolutionary origins of a trait, the latter its utility in various environmental contexts. However, both the mechanism and effect of phylogenetic inertia can impinge on the degree to which $\mathrm{CB}$ is adaptive under current circumstances, since phylogenetic history necessarily affects the form of a trait and its ability to respond to optimizing selection (Gould and Lewontin 1979). If genetic correlation with other positively selected traits is the mechanism of inertia, then the "current utility" of CB may be compromised (Lande 1982); this raises the intriguing possibility that individuals accruing proximate fitness advantages by helping may do so in the context of a social system that is neutral or "exaptive" at present, causing it to be maintained for reasons other than those for which it originally arose (Gould and Vrba 1982; Zack and Ligon 1986). On the other hand, if persistent stabilizing selection is the mechanism of stasis, CB is more aptly called adaptive throughout the inertial phase (Maynard Smith 1983; Coddington 1988).

From a phylogenetic perspective, establishing the phylogenetic coincidence of performance advantages, invasion of novel selective regimes, and the origin of $\mathrm{CB}$ is a prerequisite for calling CB adaptive (Greene 1986). Comparisons of breeder longevities, reproductive outputs, the number and quality of helpers, and other demographic parameters in cooperative breeders and nonsocial sister taxa permit assessment of the fitness advantages brought about specifically by CB and helpers' functional role (Austad and Rabenold 1985; Zack and Ligon 1986; Noske 1991; Carmen 1993). Phylogenetic and biogeographical studies of genera rich in cooperative breeders can help identify the ecological conditions surrounding the origin of CB in various clades (Russell 1989; Heinsohn et al. 1990). Acknowledg- 
ing that the evolutionary origin of helping and CB may occur prior to diversification of species rather than in the present or recent past-regardless of whether it arose adaptively - does not exclude the possibility of its having significant fitness consequences (Koenig and Mumme 1990; Emlen et al. 1991). If historical contingency exists for a phenomenon like $\mathrm{CB}$, a hypothesis supported here, then this provides what may be an important clue to understanding and quantifying the functional utility of this behavior in surviving lineages of birds.

\section{ACKNOWLEDGMENTS}

This article was originally conceived in 1988, without knowledge of E. Russell's (1989) important work. We are particularly grateful to W. Koenig and F. Pitelka for their enthusiasm in and improvement of all its myriad aspects. We especially thank J. Diamond and R. Schodde for assisting with character assignments for taxa (although all mistakes are our own); J. Cracraft, R. B. Payne, I. Rowley, and $\mathrm{E}$. Russell for suggesting references and providing unpublished data on $M a$ lurus; S. Frank, M. Kot, and W. Maddison for discussions about and performing analyses; K. de Queiroz, J. Fitzpatrick, J. Gittleman, H. Greene, I. Jamieson, T. Peterson, S. Pruett-Jones, S. Stearns, F. Villeblanca, and G. Woolfenden for insightful discussions and unpublished work; M. Rausher, P. Sherman, and S. Vail for comments and editorial assistance; and J. Brown, A. Cockburn, J. Cracraft, R. Crozier, J. Dickinson, J. Fitzpatrick, H. Ford, S. Frank, R. Honeycutt, I. Jamieson, N. Johnson, W. Koenig, J. Losos, W. Maddison, A. Meyer, J. Patton, R. B. Payne, F. Pitelka, F. Ratnieks, R. Schodde, M. Slatkin, D. Wake, M. J. West-Eberhard, the late A. Wilson, and several anonymous reviewers for helpful criticisms on various drafts. S.V.E. was supported in part by National Science Foundation Graduate and Ford Foundation Dissertation Fellowships.

\section{APPENDIX A}

TABLE A1

Summary of the Observed and Expected Numbers of Cooperatively Breeding Species in the ioo Passerine Genera Listed in Table 2.2 OF Brown (i987) ${ }^{\mathrm{a}}$

\begin{tabular}{|c|c|c|c|c|c|}
\hline Family Genus (Group) ${ }^{b}$ & $\begin{array}{l}\text { Total No. of } \\
\text { Species }\left(N_{S}\right)^{\mathrm{c}}\end{array}$ & $\begin{array}{c}\text { No. of } \\
\text { Cooperative } \\
\text { Breeders }\left(N_{0}\right)\end{array}$ & $\begin{array}{l}\text { Expected No. } \\
\text { of Cooperative } \\
\text { Breeders }\left(E_{i}\right)^{\mathrm{d}}\end{array}$ & $\begin{array}{c}\text { Observed } \\
\text { Proportion } \\
\left(N_{\mathrm{O}} / N_{\mathrm{S}}\right)\end{array}$ & $\begin{array}{l}\text { Binomial } \\
\text { Probability } \\
(>x)^{\mathrm{e}}\end{array}$ \\
\hline \multicolumn{6}{|l|}{ Tyrannidae: } \\
\hline Myiozetetes & 4 & 1 & .67 & .25 & .52 \\
\hline Conopias & 3 & 1 & .50 & .33 & .42 \\
\hline \multicolumn{6}{|l|}{ Furnariidae: } \\
\hline Phacellodomus (II) & 10 & 1 & 1.67 & .10 & .84 \\
\hline \multicolumn{6}{|l|}{ Hirundinidae: } \\
\hline Hirundo (II) & 13 & 1 & 2.17 & .08 & .91 \\
\hline \multicolumn{6}{|l|}{ Motacillidae: } \\
\hline Motacilla (II) & 10 & 1 & 1.67 & .10 & .84 \\
\hline \multicolumn{6}{|l|}{ Campephagidae: } \\
\hline Coracina (II) & 21 & 1 & 3.50 & .05 & .98 \\
\hline \multicolumn{6}{|l|}{ Laniidae: } \\
\hline Prionops (I) & 13 & 3 & 2.17 & .23 & .37 \\
\hline
\end{tabular}


TABLE A1 (Continued)

\begin{tabular}{|c|c|c|c|c|c|}
\hline Family Genus (Group) ${ }^{\mathrm{b}}$ & $\begin{array}{l}\text { Total No. of } \\
\text { Species }\left(N_{\mathrm{S}}\right)^{\mathrm{c}}\end{array}$ & $\begin{array}{c}\text { No. of } \\
\text { Cooperative } \\
\text { Breeders }\left(N_{O}\right)\end{array}$ & $\begin{array}{l}\text { Expected No. } \\
\text { of Cooperative } \\
\text { Breeders }\left(E_{i}\right)^{\mathrm{d}}\end{array}$ & $\begin{array}{c}\text { Observed } \\
\text { Proportion } \\
\left(N_{\mathrm{O}} / N_{\mathrm{S}}\right)\end{array}$ & $\begin{array}{l}\text { Binomial } \\
\text { Probability } \\
\qquad>x)^{\mathrm{e}}\end{array}$ \\
\hline Eurocephalus & 2 & 1 & .33 & .50 & .31 \\
\hline Lanius (II) & 23 & 1 & 3.83 & .04 & .99 \\
\hline Corvinella (I) & 2 & 2 & .33 & 1.00 & $.03 *$ \\
\hline \multicolumn{6}{|l|}{ Vangidae: } \\
\hline Leptopterus & 3 & 1 & .50 & .33 & .42 \\
\hline \multicolumn{6}{|l|}{ Troglodytidae: } \\
\hline Thryothorus (II) & 21 & 1 & 3.50 & .05 & .98 \\
\hline Campylorhynchus (I) & 11 & 6 & 1.83 & .55 & $.005^{*}$ \\
\hline \multicolumn{6}{|l|}{ Mimidae: } \\
\hline Nesomimus (I) & 2 & 2 & .33 & 1.00 & $.03 *$ \\
\hline \multicolumn{6}{|l|}{ Prunellidae: } \\
\hline Prunella (I) & 12 & 2 & 2.00 & .17 & .62 \\
\hline \multicolumn{6}{|l|}{ Muscicapidae: } \\
\hline Melaenornis & 6 & 1 & 1.00 & .17 & .67 \\
\hline Fraseria & 2 & 1 & .33 & .55 & .31 \\
\hline Bradornis & 4 & 1 & .67 & .25 & .52 \\
\hline Erythrocercus & 3 & 1 & .50 & .33 & .42 \\
\hline Trochocercus & 5 & 1 & .83 & .20 & .60 \\
\hline Acrocephalus (II) & 28 & 1 & 4.66 & .04 & .99 \\
\hline Eremomela $(\mathrm{I})$ & 11 & 2 & 1.83 & .18 & .57 \\
\hline Platysteira (II) & 7 & 1 & 1.17 & .14 & .72 \\
\hline \multicolumn{6}{|l|}{ Orthonychidae: } \\
\hline Cinclosoma & 4 & 1 & .67 & .25 & .52 \\
\hline Orthonyx & 2 & 1 & .33 & .50 & .31 \\
\hline \multicolumn{6}{|l|}{ Turdidae: } \\
\hline Erithacus (II) & 25 & 1 & 4.17 & .04 & .99 \\
\hline Myrmecocichla (II) & 7 & 1 & 1.17 & .14 & .72 \\
\hline Oenanthe (II) & 18 & 1 & 3.00 & .06 & .96 \\
\hline \multicolumn{6}{|l|}{ Timaliidae: } \\
\hline Pomatostomus (I) & 5 & 5 & .83 & 1.00 & $.0001^{*}$ \\
\hline Turdoides (I) & 26 & 10 & 4.33 & .38 & .007 \\
\hline \multicolumn{6}{|l|}{ Maluridae: } \\
\hline Malurus (I) & 15 & 6 & 2.50 & .40 & $.03 *$ \\
\hline \multicolumn{6}{|l|}{ Acanthizidae: } \\
\hline Gerygone (II) & 19 & 2 & 3.17 & .11 & .85 \\
\hline Sericornis (II) & 15 & 2 & 2.50 & .13 & .74 \\
\hline Acanthiza (I) & 13 & 5 & 2.17 & .38 & .05 \\
\hline \multicolumn{6}{|l|}{ Eopsaltriidae: } \\
\hline Eopsaltria (I) & 4 & 3 & .67 & .75 & $.02^{*}$ \\
\hline Petroica (II) & 12 & 1 & 2.00 & .08 & .89 \\
\hline \multicolumn{6}{|l|}{ Aegithalidae: } \\
\hline Aegithalos & 5 & 1 & .83 & .20 & .56 \\
\hline Psaltriparus & 2 & 1 & .33 & .50 & .31 \\
\hline \multicolumn{6}{|l|}{ Paridae: } \\
\hline Parus (II) & 45 & 2 & 7.50 & .04 & .99 \\
\hline \multicolumn{6}{|l|}{ Sittidae: } \\
\hline Sitta (II) & 21 & 2 & 3.50 & .10 & .89 \\
\hline \multicolumn{6}{|l|}{ Climacteridae: } \\
\hline Climacteris (I) & 6 & 4 & 1.00 & .67 & $.009^{*}$ \\
\hline \multicolumn{6}{|l|}{ Dicaeidae: } \\
\hline Pardalotus (II) & 8 & 1 & 1.33 & .13 & .77 \\
\hline \multicolumn{6}{|l|}{ Zosteropidae: } \\
\hline Zosterops (II) & 61 & 1 & 10.16 & .02 & .99 \\
\hline \multicolumn{6}{|l|}{ Meliphagidae: } \\
\hline Phylidonyris (II) & 7 & 1 & 1.17 & .14 & .72 \\
\hline Anthochaera & 4 & 1 & .67 & .25 & $\begin{array}{l}.52 \\
\text { (contir }\end{array}$ \\
\hline
\end{tabular}


TABLE A1 (Continued)

\begin{tabular}{|c|c|c|c|c|c|}
\hline Family Genus (Group) ${ }^{\mathrm{b}}$ & $\begin{array}{c}\text { Total No. of } \\
\text { Species }\left(N_{\mathrm{S}}\right)^{\mathrm{c}}\end{array}$ & $\begin{array}{c}\text { No. of } \\
\text { Cooperative } \\
\text { Breeders }\left(N_{\mathrm{O}}\right)\end{array}$ & $\begin{array}{l}\text { Expected No. } \\
\text { of Cooperative } \\
\text { Breeders }\left(E_{i}\right)^{\mathrm{d}}\end{array}$ & $\begin{array}{c}\text { Observed } \\
\text { Proportion } \\
\left(N_{\mathrm{O}} / N_{\mathrm{S}}\right)\end{array}$ & $\begin{array}{l}\text { Binomial } \\
\text { Probability } \\
(>x)^{\mathrm{e}}\end{array}$ \\
\hline Manorina (I) & 4 & 3 & .67 & .75 & $.02 *$ \\
\hline Lichenostomus (II) & 21 & 2 & 3.50 & .10 & .89 \\
\hline Conopophila & 4 & 1 & .67 & .25 & .52 \\
\hline Melithreptus (I) & 7 & 3 & 1.17 & .43 & .10 \\
\hline Philemon (II) & 16 & 1 & 2.67 & .06 & .95 \\
\hline \multicolumn{6}{|l|}{ Emberizidae: } \\
\hline Emberiza (II) & 38 & 1 & 6.33 & .03 & .99 \\
\hline Aimophila (II) & 14 & 1 & 2.33 & .07 & .92 \\
\hline Geospiza (I) & 6 & 2 & 1.00 & .33 & .26 \\
\hline Cardinalis & 3 & 1 & .50 & .33 & .42 \\
\hline Tanagra (II) & 47 & 4 & 7.83 & .09 & .97 \\
\hline Curaeus & 2 & 1 & .33 & .50 & .31 \\
\hline Pseudoleistes & 2 & 1 & .33 & .50 & .31 \\
\hline Molothrus & 5 & 1 & .83 & .20 & .56 \\
\hline \multicolumn{6}{|l|}{ Ploceidae: } \\
\hline Pseudonigrita & 2 & 1 & .33 & .50 & .31 \\
\hline Plocepasser & 4 & 1 & .67 & .25 & .52 \\
\hline Passer (II) & 15 & 1 & 2.50 & .07 & .99 \\
\hline \multicolumn{6}{|l|}{ Sturnidae: } \\
\hline Lamprotornis (II) & 16 & 1 & 2.67 & .06 & .95 \\
\hline Cosmopsarus (I) & 2 & 2 & .33 & 1.00 & $.03 *$ \\
\hline Spreo (I) & 6 & 4 & 1.00 & .67 & $.009 *$ \\
\hline Buphagus (I) & 2 & 2 & .33 & 1.00 & $.03 *$ \\
\hline \multicolumn{6}{|l|}{ Dicruridae: } \\
\hline Dicrurus (II) & 19 & 2 & 3.17 & .11 & .85 \\
\hline Artamidae: & & & & & \\
\hline Artamus (I) & 10 & 4 & 1.67 & .40 & .07 \\
\hline \multicolumn{6}{|l|}{ Cracticidae: } \\
\hline Cracticus (I) & 4 & 2 & .67 & .50 & .13 \\
\hline \multicolumn{6}{|l|}{ Corvidae: } \\
\hline Aphelocoma (I) & 3 & 3 & .50 & 1.00 & $.005^{*}$ \\
\hline Cyanocorax (I) & 11 & 6 & 1.83 & .55 & $.005^{*}$ \\
\hline Corvus (II) & 38 & 2 & 6.33 & .05 & .99 \\
\hline Total (71 genera): & 840 & 140 & 140 & $\cdots$ & \\
\hline Mean & 11.83 & 1.97 & 1.97 & .32 & \\
\hline SD & 11.81 & 1.64 & 1.97 & $\ldots$ & \\
\hline
\end{tabular}

${ }^{\text {a }}$ Here, group designation (I or II) corresponds to the divisions in fig. 2 . Those genera in which the proportion of cooperative species is greater than or equal to $140 / 840$ (excluding those in which a single cooperative breeder belongs to a genus of six species or less) are designated Group I $(n=22)$; those in which the proportion is less, Group II $(n=28)$. Those genera containing a single cooperative breeder and six species or less receive no designation (see also text).

b The following 26 monotypic genera (family in parentheses) are listed as cooperative breeders in table 2.2 of Brown (1987): Philetarius, Donacobius, Querula (Cotingidae), Colius (Coliidae), Yuhina, Chrysomma (Timaliidae), Ixonotus, Thescelocichla (Pycnonotidae), Chaetops, Daphoenositta, Smicrornis, Cettia, Melaenornis, Falcunculus (Muscicapidae), Plectorhyncha (Meliphagidae), Dolichonyx, Oreospar (Emberizidae), Pholidornis (Estrildidae), Struthidea, Corcorax (Grallinidae), Gymnorhina (Cracticidae), Zavattariornis, Ptilostomus, Psilorhinus, Calocitta, Cyanopica, Gymnorhinus (Corvidae).

${ }^{c}$ As determined from Morony et al. (1975) and Howard and Moore (1984). Nesomimus is listed as two species in table 2.2 of Brown (1987).

${ }^{d}$ Based on calculations outlined in Methods.

${ }^{\mathrm{e}}$ Binomial probability of having the expected ratio of cooperative and noncooperative breeders in the genus, where the frequency $(p)$ of cooperative breeders $=140 / 840=0.1667$, and $(q)=700 / 840$ $=0.8333$. Asterisks mark those ratios significantly different than the expected. Probabilities approaching one $(>.95)$ indicate genera poorer in cooperative breeders than expected. 


\section{APPENDIX B}

TABLE B1

Interspecific Difference Matrix Used for Comparative Analysis of Group Size in Australian Babblers (Pomatostomus) in TABle 4

\begin{tabular}{lccccc}
\hline \hline Species & 1 & 2 & 3 & 4 & 5 \\
\hline 1. P. temporalis & 17.5 & 17.5 & 23.2 & 24.8 & 34.1 \\
2. P. halli & 23.2 & 24.2 & 24.2 & 28.0 & 33.5 \\
3. P. superciliosus & 24.8 & 28.0 & 21.7 & 21.7 & 34.0 \\
4. P. ruficeps & 34.1 & 33.5 & 34.0 & 33.0 & 3.0 \\
5. P. isidori & & & & & \\
\hline
\end{tabular}

Note.-The matrix was used in conjunction with the mean group sizes for each species using the method of Gittleman and Kot (1990); see table 4. The matrix shows the average number of observed differences for a portion of the mitochondrial cytochrome $b$ gene for multiple comparisons among individuals of all five babbler species analyzed in Edwards and Wilson (1990). The numbers of differences were not corrected for multiple substitutions at the same nucleotide site.

\section{LITERATURE CITED}

Allard, M. W., and R. L. Honeycutt. 1991. Nucleotide sequence variation in the mitochondrial 12S rRNA gene and the phylogeny of African mole-rats (Rodentia: Bathyergidae). Molecular Biology and Evolution 9:27-40.

Arnold, S. J. 1990. Inheritance and the evolution of behavioral ontogenies. Pages 167-189 in M. E. Hahn, J. K. Hewitt, N. D. Henderson, and R. Benno, eds. Developmental behavior genetics. Oxford University Press, Oxford.

1992. Constraints on phenotypic evolution. American Naturalist 140:S85-S107.

Atz, J. W. 1970. The application of the idea of homology to behavior. Pages 53-74 in L. R. Aronson, E. Tobach, D. S. Lehrman, and J. S. Rosenblatt, eds. Development and evolution of behavior: essays in memory of T. C. Schneirla. W. H. Freeman, San Francisco.

Austad, S. N., and K. N. Rabenold. 1985. Reproductive enhancement by helpers and an experimental inquiry into its mechanism in the bicolored wren. Behavioral Ecology and Sociobiology 17:19-27.

Baroni Urbani, C. 1989. Phylogeny and behavioral evolution in ants, with a discussion of the role of behaviour in evolutionary processes. Ethology, Ecology, and Evolution 1:137-168.

Baum, D. A., and A. Larson. 1991. Adaptation reviewed: a phylogenetic methodology for studying character macroevolution. Systematic Zoology 40:1-18.

Beehler, B. M., T. K. Pratt, and D. A. Zimmerman. 1986. Birds of New Guinea. Princeton University Press, Princeton, N.J.

Bell, H. L. 1982. Social organization and feeding of the rufous babbler Pomatostomus isidori. Emu $82: 7-11$.

Berthold, P. 1991. Genetic control of migratory behaviour in birds. Trends in Ecology \& Evolution 6:254-257.

Berthold, P., W. Wiltchko, H. Miltenberger, and U. Querner. 1989. Genetic transmission of migratory behavior into a nonmigratory bird population. Experentia (Basel) 46:107-108.

Björklund, M. 1991. Evolution, phylogeny, sexual dimorphism and mating system in the grackles (Quiscalus spp. Icterinae). Evolution 45:608-621.

Blakers, M., S. J. J. F. Davies, and P. N. Reilly. 1984. The atlas of Australian birds. Melbourne University Press, Melbourne.

Boehm, E. F. 1974. Results from banding chestnut-crowned babblers. Australian Bird Bander $12: 76-78$.

Brooks, D. R. 1985. Historical ecology: a new approach to studying the evolution of ecological associations. Annals of the Missouri Botanical Garden 72:660-680. 
Brooks, D. R., and D. A. McLennan. 1990. Phylogeny, ecology and behavior. University of Chicago Press, Chicago.

Brown, J. L. 1974. Alternate routes to sociality in jays-with a theory for the evolution of altruism and communal breeding. American Zoologist 14:63-80.

1978. Avian heirs of territory. BioScience 28:750-752.

1987. Helping and communal breeding in birds: ecology and evolution. Princeton University Press, Princeton, N.J.

Brown, J. L., and R. P. Balda. 1977. The relationship of habitat quality and group size in Hall's babbler (Pomatostomus halli). Condor 79:312-320.

Brown, J. L., and E. G. Horvath. 1989. Geographic variation in group size, ontogeny, rattle calls, and body size in Aphelocoma ultramarina. Auk 106:124-128.

Brown, J. L., D. D. Dow, E. R. Brown, and S. D. Brown. 1983. Socioecology of the grey-crowned babbler (Pomatostomus temporalis): population structure, unit size, and vegetation correlates. Behavioral Ecology and Sociobiology 13:115-124.

Bull, J. J., and E. L. Charnov. 1985. On irreversible evolution. Evolution 39:1149-1155.

Burke, T., N. B. Davies, M. W. Bruford, and B. J. Hatchwell. 1989. Parental care and mating behaviour of polyandrous dunnocks Prunella modularis related to paternity by DNA fingerprinting. Nature (London) 338:249-251.

Burt, A. 1989. Comparative methods using phylogenetically independent contrasts. Oxford Surveys in Evolutionary Biology 6:33-53.

Carmen, W. J. 1993. Behavioral ecology of the California scrub jay: a non-cooperative breeder with close cooperative relatives. Studies in Avian Biology (in press).

Carpenter, J. M. 1989. Testing scenarios: wasp social behavior. Cladistics 1989:131-144.

Charlesworth, B., R. Lande, and M. Slatkin. 1982. A neodarwinian commentary on macroevolution. Evolution 36:474-498.

Cheverud, J. M., M. M. Dow, and W. Leutenegger. 1985. The quantitative assessment of phylogenetic constraints in comparative analyses: sexual dimorphism in body weights among primates. Evolution 39:1335-1351.

Clutton-Brock, T. H., and P. W. Harvey. 1979. Comparison and adaptation. Proceedings of the Royal Society of London Series B, Biological Sciences 205:547-565.

Coddington, J. A. 1988. Cladistic tests of adaptational hypotheses. Cladistics 4:3-22.

Cooper, R. P. 1969. Multiple feeding habits of wrens. Australian Bird Watcher 3:145-150.

Counsilman, J. J. 1977. A comparison of two populations of the grey-crowned babbler. I. Bird Behaviour 1:43-82.

Cracraft, J. 1986. Origin and evolution of continental biotas: speciation and historical congruence within the Australian avifauna. Evolution 40:977-996.

1987. DNA hybridization and avian phylogenetics. Evolutionary Biology 21:47-96.

Curry, R. L., and P. R. Grant. 1990. Galápagos mockingbirds: territorial cooperative breeding in a climatically variable environment. Pages 291-331 in P. B. Stacey and W. D. Koenig, eds. Cooperative breeding in birds: long-term studies of ecology and behavior. Cambridge University Press, Cambridge.

Davis, D. E. 1942. The phylogeny of social nesting in the Crotophaginae. Quarterly Review of Biology 17:115-134.

Diamond, J. 1990. Biological effects of ghosts. Nature (London) 345:769-770.

Donoghue, M. J. 1989. Phylogenies and the analysis of evolutionary sequences, with examples from seed plants. Evolution 43:1137-1156.

Dow, D. D. 1980. Communally breeding Australian birds with an analysis of distributional and environmental factors. Emu 80:121-140.

Edwards, S. V., and A. C. Wilson. 1990. Phylogenetically informative length polymorphism and sequence variability in mitochondrial DNA of Australian songbirds (Pomatostomus). Genetics 126:695-711.

Edwards, S. V., P. Arctander, and A. C. Wilson. 1991. Mitochondrial resolution of a deep branch in the genealogical tree for perching birds. Proceedings of the Royal Society of London B, Biological Sciences 243:99-107.

Eldredge, N., and S. J. Gould. 1972. Punctuated equilibria: an alternative to phyletic gradualism. 
Pages 82-115 in T. J. M. Schopf, ed. Models in paleobiology. Freeman, Cooper, San Francisco.

Emlen, S. T. 1982. The evolution of helping. I. An ecological constraints model. American Naturalist 119:29-39.

1991. Cooperative breeding in birds and mammals. Pages 301-337 in J. R. Krebs and N. B. Davies, eds. Behavioural ecology: an evolutionary approach. 3d ed. Blackwell Scientific, Oxford.

Emlen, S. T., and P. H. Wrege. 1988. The role of kinship in helping decisions among white-fronted bee-eaters. Behavioral Ecology and Sociobiology 23:305-315.

1989. A test of alternative hypotheses of the adaptive significance of helping behavior in white-fronted bee-eaters of Kenya. Behavioral Ecology and Sociobiology 25:303-319.

Emlen, S. T.; F. L. W. Ratnieks, H. K. Reeve, J. Shellman-Reeve, P. W. Sherman, and P. H. Wrege. 1991. Adaptive versus non-adaptive explanations of behavior: the case of alloparental helping. American Naturalist 138:259-270.

Fairbairn, D. J., and D. A. Roff. 1990. Genetic correlations among traits determining migratory tendency in the sand cricket, Gryllus firmus. Evolution 44:1787-1795.

Felsenstein, J. 1985. Phylogenies and the comparative method. American Naturalist 125:1-15.

Ford, J. 1979. Speciation or subspeciation in the yellow robins? Emu 79:103-106.

Ford, H. A. 1989. Ecology of birds: an Australian perspective. Surrey Beatty, Chipping Norton, Australia.

Ford, H. A., H. Bell, R. Nias, and R. Noske. 1988. The relationship between ecology and the incidence of cooperative breeding in Australian birds. Behavioral Ecology and Sociobiology 22:239-249.

Fry, C. H. 1977. The evolutionary significance of cooperative breeding in birds. Pages 127-135 in B. Stonehouse and C. Perrins, eds. Evolutionary ecology. Macmillan, London.

Gittleman, J. L., and M. Kot. 1990. Adaptation statistics and a null model for estimating phylogenetic effects. Systematic Zoology 39:227-241.

Goodwin, D. 1976. Crows of the world. Gresham, Old Woking, England.

Gould, S. J., and R. C. Lewontin. 1979. The spandrels of San Marco and the Panglossian paradigm: a critique of the adaptationist program. Proceedings of the Royal Society of London B, Biological Sciences 205:581-598.

Gould, S. J., and E. Vrba. 1982. Exaptation-a missing term in the science of form. Paleobiology 8:4-15.

Grafen, A. 1989. The phylogenetic regression. Philosophical Transactions of the Royal Society of London 326:119-159.

Gray, R. D. 1989. Oppositions in panbiogeography: can the conflicts between selection, constraint, ecology, and history be resolved? New Zealand Journal of Zoology 16:787-806.

Greene, H. W. 1986. Diet and arborality in the emerald monitor, Varanus prasinus, with comments on the study of adaptation. Fieldiana Zoology, N.S., 31:1-12.

Greene, H. W., and G. M. Burghardt. 1978. Behavior and phylogeny: constriction in ancient and modern snakes. Science (Washington, D.C.) 200:74-77.

Hamilton, W. D. 1964. The genetical evolution of social behavior. I, II. Journal of Theoretical Biology 7:1-52.

Hardy, J. W. 1961. Studies in behavior and phylogeny of certain New World jays (Garrulinae). University of Kansas Science Bulletin 42:13-149.

1969. A taxonomic revision of the New World jays. Condor 71:360-375.

1974. Behavior and its evolution in Neotropical jays (Cissilopha). Bird-Banding 45:253268.

Harrison, C. J. O. 1969. Helpers at the nest in Australian birds. Emu 69:30-40.

Harvey, P., and M. Pagel. 1991. The comparative method in evolutionary biology. Oxford University Press, Oxford.

Heinsohn, R. G. 1991. Slow learning of foraging skills and extended parental care in cooperatively breeding white-winged choughs. American Naturalist 137:864-881.

Heinsohn, R. G., A. Cockburn, and R. A. Mulder. 1990. Avian cooperative breeding: old hypotheses and new directions. Trends in Ecology \& Evolution 5:403-407. 
Helbig, A. 1990. Are orientation mechanisms among migratory birds species-specific? Trends in Ecology \& Evolution 5:365-366.

Helm-Bychowski, K., and A. C. Wilson. 1986. Rates of nuclear DNA evolution in pheasant-like birds: evidence from restriction maps. Proceedings of the National Academy of Sciences of the USA 83:688-692.

Höglund, J. 1989. Size and plumage dimorphism in lek-breeding birds: a comparative analysis. American Naturalist 134:72-87.

Honeycutt, R. L., S. V. Edwards, K. Nelson, and E. Nevo. 1987. Mitochondrial DNA variation and the phylogeny of African mole rats (Rodentia: Bathyergidae). Systematic Zoology 36:280-292.

Honeycutt, R. L., M. W. Allard, S. V. Edwards, and D. A. Schlitter. 1991. Systematics and evolution of the family Bathyergidae. Pages $45-65$ in P. W. Sherman, J. U. M. Jarvis, and R. D. Alexander, eds. The biology of the naked mole-rat. Princeton University Press, Princeton, N.J.

Howard, R., and A. Moore. 1984. A complete checklist of birds of the world. Macmillan, London.

Huey, R. B. 1987. Phylogeny, history and the comparative method. Pages 76-101 in M. E. Feder, A. F. Bennett, W. W. Burggren, and R. B. Huey, eds. New directions in ecological physiology. Cambridge University Press, Cambridge.

Huey, R. B., and A. F. Bennett. 1987. Phylogenetic studies of coadaptation: preferred temperatures versus optimal performance temperatures of lizards. Evolution 41:1098-1115.

Jamieson, I. 1989. Behavioral heterochrony and the evolution of birds' helping at the nest: an unselected consequence of communal breeding? American Naturalist 127:195-208.

1991. The unselected hypothesis for the evolution of helping behavior-too much or too little emphasis on natural selection? American Naturalist 138:271-282.

Jamieson, I., and J. L. Craig. 1987. Critique of helping behavior in birds: a departure from functional explanations. Pages 79-98 in P. Bateson and P. Klopfer, eds. Perspectives in ethology. Vol. 7. Plenum, New York.

Janzen, D. H., and P. Martin. 1982. Neotropical anachronisms: what the gomphotheres ate. Science (Washington, D.C.) 215:19-27.

Keast, A. 1961. Bird speciation on the Australian continent. Bulletin of the Museum of Comparative Zoology 123:303-495.

Kirkpatrick, M., and M. J. Ryan. 1991. The evolution of mating preferences and the paradox of the lek. Nature (London) 350:33-38.

Koenig, W. D., and R. L. Mumme. 1990. Levels of analysis, functional explanations, and the significance of helping behavior. Pages 268-303 in M. Beckoff and D. Jamieson, eds. Interpretation and explanation in the study of behavior. Vol. 2. Westview, Boulder, Colo.

Koenig, W. D., and F. A. Pitelka. 1981. Ecological factors and kin selection in the evolution of cooperative breeding in birds. Pages 261-280 in R. D. Alexander and D. W. Tinkle, eds. Natural selection and social behavior: recent research and new theory. Chiron, New York.

Laland, K. N. 1991. A theoretical investigation of the role of social transmission in evolution. Ethology and Sociobiology 13:87-113.

Lande, R. 1978. Evolutionary mechanisms of limb loss in tetrapods. Evolution 32:73-92. 1982. A quantitative genetic theory of life history evolution. Ecology 63:607-615.

Le Quesne, W. J. 1974. The uniquely evolved character concept and its cladistic application. Systematic Zoology 23:513-517.

Lewontin, R. C. 1974. The analysis of variance and the analysis of causes. American Journal of Human Genetics 26:400-411.

Ligon, J. D. 1992. The role of phylogenetic history in the evolution of contemporary avian mating systems and parental care systems. Current Ornithology (in press).

Lorenz, K. 1950. The comparative method of studying innate behavior patterns. Symposia of the Society for Experimental Biology 4:221-268.

Losos, J. B. 1990. Ecomorphology, performance capability, and scaling of West Indian Anolis lizards: an evolutionary analysis. Ecological Monographs 60:369-388.

Lynch, M. 1991. Methods for the analysis of comparative data in evolutionary biology. Evolution 45:1065-1080. 
Maddison, W. P. 1989. Reconstructing character evolution on polytomous cladograms. Cladistics 5:365-377.

-1990. A method for testing the correlated evolution of two binary characters: are gains or losses concentrated on certain branches of a phylogenetic tree? Evolution 44:539-557.

Maddison, W. P., M. J. Donoghue, and D. R. Maddison. 1984. Outgroup analysis and parsimony. Systematic Zoology 33:38-103.

Martins, E. P., and T. Garland, Jr. 1991. Phylogenetic analysis of the correlated evolution of continuous characters: a simulation study. Evolution 45:534-558.

Marzluff, J. M., and R. P. Balda. 1990. Pinyon jays: making the best of a bad situation by helping. Pages 197-237 in P. B. Stacey and W. D. Koenig, eds. Cooperative breeding in birds: long-term studies of ecology and behavior. Cambridge University Press, Cambridge.

Maynard Smith, J. 1983. The genetics of stasis and punctuation. Annual Review of Genetics 17:11-25.

Mayr, E. 1958. Behavior and systematics. Pages 341-366 in A. Roe and G. G. Simpson, eds. Behavior and evolution. Yale University Press, New Haven, Conn.

McLennan, D. A., D. R. Brooks, and J. D. McPhail. 1988. The benefits of communication between comparative ethology and phylogenetic systematics: a case study using gasterosteid fishes. Canadian Journal of Zoology 66:2177-2190.

Michener, C. D., and D. A. Grimaldi. 1988. The oldest fossil bee: apoid history, evolutionary stasis and the antiquity of social behavior. Proceedings of the National Academy of Sciences of the USA 85:6424-6426.

Morony, J. J., W. J. Bock, and J. Farrand. 1975. Reference list of the birds of the world. American Museum of Natural History, New York.

Nix, H. A. 1976. Environmental control of breeding, post-breeding dispersal and migration of birds in the Australian region. Proceedings International Ornithological Congress 16:275-305.

Norris, R. A. 1958. Comparative biosystematics and life history of the nuthatches Sitta pygmaea and Sitta pusilla. University of California Publications in Zoology 56:119-300.

Noske, R. A. 1980. Cooperative breeding by treecreepers. Emu 80:35-36.

1991. A demographic comparison of cooperatively breeding and non-cooperative treecreepers (Climacteridae). Emu 91:73-86.

Partridge, L., and P. H. Harvey. 1988. The ecological context of life history evolution. Science (Washington, D.C.) 241:1449-1455.

Payne, R. B. 1986. Bird songs and avian systematics. Current Ornithology 3:87-126.

Peterson, A. T. 1991a. Phylogeny and rates of molecular evolution in the Aphelocoma jays (Corvidae). Auk 109:133-147.

$1991 b$. Sociality and ontogeny of coloration in the blue-and-black jays. Wilson Bulletin 103:59-67.

Pitelka, F. A. 1951. Speciation and ecologic distribution in American jays of the genus Aphelocoma. University of California Publications in Zoology 50:195-464.

Potts, W. J., C. J. Manning, and E. K. Wakeland. 1991. Mating patterns in seminatural populations of mice influenced by MHC genotype. Nature (London) 352:619-621.

Price, T., and D. Schluter. 1991. On the low heritability of life-history traits. Evolution 54:853-861.

Pruett-Jones, S. G., and M. J. Lewis. 1990. Sex ratio and habitat limitation promote delayed dispersal in superb fairy-wrens. Nature (London) 348:541-542.

Prum, R. O. 1990. Phylogenetic analysis of the evolution of display behavior in the Neotropical manakins (Aves: Pipridae). Ethology 84:202-231.

Rabenold, K. N. 1990. Campylorhynchus wrens: the ecology of delayed dispersal and cooperation in the Venezuelan savanna. Pages 159-196 in P. B. Stacey and W. D. Koenig, eds. Cooperative breeding in birds: long-term studies of ecology and behavior. Cambridge University Press, Cambridge.

Rand, A. L., and E. T. Gilliard. 1967. Handbook of New Guinea birds. Natural History Press, New York.

Ridley, M. 1983. The explanation of organic diversity: the comparative method and adaptations for mating. Clarendon, Oxford.

Riedl, R. 1978. Order in living systems. Wiley, New York. 
Ross, K. G., and J. M. Carpenter. 1991. Phylogenetic analysis of queen number in the eusocial Hymenoptera. Journal of Evolutionary Biology 4:117-130.

Rowley, I. 1965. The life history of the superb blue wren, Malurus cyaneus. Emu 64:251-297.

1968. Communal species of Australian birds. Bonner Zoologische Beiträge 19:362-368.

1976. Co-operative breeding in Australian birds. Proceedings of the 16th International Ornithological Congress 16:657-666.

1978. Communal activities among white-winged choughs, Corcorax melanorhamphos. Ibis 120:178-197.

Rowley, I., E. Russell, R. B. Payne, and L. L. Payne. 1989. Plural breeding in the splendid fairy-wren, Malurus splendens (Aves: Maluridae), a cooperative breeder. Ethology 83:229-247.

Russell, E. 1989. Co-operative breeding-a Gondwanan perspective. Emu 89:61-62.

Sarich, V., C. W. Schmid, and J. Marks. 1989. DNA hybridization as a guide to phylogenies: a critical analysis. Cladistics 5:3-32.

Schodde, R. 1982a. Origin, adaptation and evolution of birds in arid Australia. Pages 191-224 in W. R. Barker and P. J. M. Greenslade, eds. Evolution of the flora and fauna of arid Australia. Peacock, Frewville, Australia.

1982b. The fairy wrens. Lansdowne, Melbourne.

Schodde, R., and S. C. Tidemann, eds. 1986. Readers digest complete book of Australian birds. Readers Digest Service, Sydney.

Selander, R. K. 1964. Speciation in wrens of the genus Campylorhynchus. University of California Publications in Zoology 74:1-259.

Sherman, P. W. 1988. The levels of analysis. Animal Behaviour 36:616-619.

Short, L. L. 1970. Notes on the habits of some Argentine and Peruvian woodpeckers (Aves: Picidae). American Museum Novitates 2413:1-37.

1982. Woodpeckers of the world. Delaware Museum of Natural History, Greenville.

Sibley, C. G., and J. E. Ahlquist. 1985. The phylogeny and classification of the Australo-Papuan passerine birds. Emu 85:1-14.

Sibley, C. G., J. E. Ahlquist, and B. L. Monroe, Jr. 1988. A classification of the living birds of the world based on DNA-DNA hybridization studies. Auk 105:409-423.

Sillen-Tullberg, B. 1988. Evolution of gregariousness in aposematic butterfly larvae: a phylogenetic analysis. Evolution 42:293-305.

Skutch, A. F. 1935. Helpers at the nest. Auk 52:257-273. 1961. Helpers among birds. Condor 63:198-226.

Slatkin, M. 1983. Genetic background. Pages 14-32 in D. Futuyma and M. Slatkin, eds. Coevolution. Sinauer, Sunderland, Mass.

Stacey, P. B., and C. E. Bock. 1978. Social plasticity in the acorn woodpecker. Science (Washington, D.C.) 202:1298-1300.

Swofford, D. L. 1990. PAUP: phylogenetic analysis using parsimony. Version 3.0g. Illinois Natural History Survey, Champaign.

Tidemann, S. C. 1986. Breeding in three species of fairy wrens (Malurus): do helpers really help? Emu 86:131-138.

van Noordwijk, A. J. 1989. Reaction norms in genetical ecology. BioScience 39:453-459.

Wake, D. B., G. Roth, and M. H. Wake. 1983. On the problem of stasis in organismal evolution. Journal of Theoretical Biology 101:211-224.

Wcislo, W. T. 1989. Behavioral environments and evolutionary change. Annual Review of Ecology and Systematics 20:137-169.

West-Eberhard, M. J. 1987. The epigenetical origins of insect sociality. Pages 369-372 in J. Eder and H. Rembold, eds. Chemistry and biology of social insects. Peperny, Munich.

Williams, G. C. 1966. Adaptation and natural selection. Princeton University Press, Princeton, N.J.

Wilson, A. C. 1989. Time scale for bird evolution. Proceedings of the International Ornithological Congress 19:1912-1917.

Wilson, A. C., M. Stoneking, and R. L. Cann. 1991. Ancestral geographic states and the peril of parsimony. Systematic Zoology 40:363-365.

Wilson, E. O. 1971. The insect societies. Harvard University Press, Cambridge, Mass. 1975. Sociobiology. Belknap, Cambridge, Mass. 
Woolfenden, G. E., and J. W. Fitzpatrick. 1984. The Florida scrub jay: demography of a cooperativebreeding bird. Princeton University Press, Princeton, N.J.

Wright, S. 1968. Evolution and the genetics of populations. Vol. I. Genetic and biometric foundations. University of Chicago Press, Chicago.

Yamashina, M. 1938. A sociable breeding habit among timaliine birds. Proceedings of the International Ornithological Congress 9:453-456.

Yom-Tov, Y. 1987. The reproductive rates of Australian passerines. Australian Wildlife Research 14:319-330.

Zack, S., and J. D. Ligon. 1986. Cooperative breeding in Lanius shrikes. II. Maintenance of group living in a nonsaturated habitat. Auk 102:766-773.

Associate Editor: Paul W. Sherman 